\title{
JULES VERNE Y H. P. LOVECRAFT O UNAS TEORÍAS PARA LA HISTORIA
}

\author{
Pascual Raga Rosaleny
}

UNED

RESUMEN: Dos revolucionarios y geniales escritores, aunados además por su péñola de tendencia antirrealista tanto como por el occidentalismo del Atlántico, nos van a ayudar a teorizar sobre el estudio de la historia; dicha tendencia literaria fue parcial en el primero de ellos, e integral en el segundo, siendo Occidente el genético horizonte de ambos. La primera cuestión solidaria, con ser de grado, en verdad es irrelevante para nuestro empeño, ya que de Verne nos interesa especialmente una de sus obras realistas, y de Lovecraft sobretodo uno de sus textos de ensayo. Además, nuestra apropiación de Verne está mediada filosóficamente, entretanto la correspondiente recepción de Lovecraft la observamos mediada desde la literatura.

Palabras clave: Teorías, métodos, epistemes, filosofías, literaturas, metáforas, historia.

\section{JULES VERNE AND H. P. LOVECRAFT OR THEORIES ABOUT THE HISTORY}

ABSTRACT: Two revolutionaries and brillant writers, united in addition by his fountain pen of trend unrealist so much like for the occidentalism of the Atlantic Ocean, us are going to help to theorize on the study of the history; the above mentioned literary trend was partial in the first one of them, and integral in the second one, being Western the generic horizon of both. The first solidary question, in spite of being of degree, really is irrelevant for our determination, since of Verne we are interested specially in one of his realistic works, and of Lovecraft overcoat one of his texts of test. In addition, our Verne's appropriation is half-full philosophically, meanwhile we observe Lovecraft's corresponding receipt happened from literature.

Keywords: Theories, methods, epistemes, philosophies, literatures, metaphors, history. 


\section{Los hijos del capitán Grant, "de" Agnes Heller}

Para la filosofía, seguramente sea acertado callar cuando no se tiene nada que decir, como pedía Wittgenstein ${ }^{1}$, quien además lo puso en práctica durante seis largos años; empero, uno de los elementos más importantes para la cliología ${ }^{2}$ es la redundancia, sin la cual no tendríamos -por ejemplo- la especialidad historiológica ${ }^{3}$ de la historia oral, preclara fuente de tantísimos otros conocimientos. Tampoco la comunicación se podría dar sin redundancias. Ni el ser. Ni el amor. Ni la misma vida. Deo gracias, la filósofa Agnes Heller sí tiene mucho que decirnos, además de emplear también la redundancia en su teorización cliológica. Comenzando por el plano más básico, el comunicativo, la repetición es imprescindible -como ya decíamos-, porque son tantísimas las palabras y giros que hemos de repetir a fin de enhebrar cualquier discurso; lo mismo ocurre con los recuerdos, fundamento de la memoria, la cual a su vez es la base de la historia. Pero, ¿qué hemos de recordar?, ¿qué memoria histórica necesitamos? En primera instancia, sin que el orden apele a ninguna jerarquía, desde luego necesitamos una memoria identitaria ${ }^{4}$, aunque para ser histórica deberá además corregir los excesos de la mnemosyne, es decir, debe recordar lo positivo y lo negativo de nuestros pasados; y ello no porque vayamos a desterrar los mitos, ya que a una mítica arrumbada le sucede indefectiblemente otra ${ }^{5}$, sino para ir denunciando los caracteres míticos como único medio de atemperarlos al tomar conciencia de los mismos. En segundo lugar, debemos recordar la injusticias cometidas, más aún, debemos fomentar la memoria histórica de los vencidos, del lumpen-

1. WITTGENSTEIN, Ludwig H.: Tractatus logico-philosophicus. Madrid, Tecnos, 2002, p. 277, donde dice exactamente: "De lo que no se puede hablar, hay que callar la boca".

2. Es decir, la ciencia que estudia la historia. Este término ("cliología") ya lo hemos defendido en ocasiones anteriores, pues elimina las ambigüedades generadas al nominar con el mismo vocablo el objeto y la ciencia que lo estudia.

3. ORTEGA Y GASSET, José: "La «Filosofía de la Historia» de Hegel y la Historiología", en HEGEL, Georg W. F.: Lecciones sobre la Filosofía de la Historia Universal. Madrid, Alianza, 2008, pp. 13-32.

4. YERUSHALMI, Yosef H.: Zajor. La historia judía y la memoria judía. Barcelona, Anthropos, 2002.

5. CUETO, Juan: Mitologías de la modernidad. Barcelona, Salvat, 1982, p. 5, quien nos dice que ahora "como antes, en la antigüedad o en la posmodernidad, los mitos se refieren a los orígenes, pero son hijos de las transiciones. [...] Nos remiten al origen de todas las cosas actuales y lo hacen, principalmente, a través de los nuevos héroes, dioses y semidioses del mercado, que reinan en la audiencia como antaño reinaban en el Olimpo. [Ya] se sabe y es fama desde los principios de la humanidad [que] los períodos de transición son períodos de incertidumbre, de convulsiones, de crisis, de empobrecimiento estructural... Pero sobretodo, y por eso mismo, son períodos de gran riqueza mítica y simbólica".

6. BENJAMIN, Walter: Libro de los pasajes. Madrid, Akal, 2005, p. 462, nos advierte de la centralidad de los trapos (lumpen) o harapos, de los desechos (abfall), tanto para la historia 
sammler6 (trapero); esta "recordación"7, como quiere Benjamin, es la que nos puede poner al abrigo de perpetuar lo indebido, esto es: la única forma de ir remediando aquel mal que fue, no porque cambiemos el pasado, que no se puede cambiar, sino porque lo troquemos hoy en un bien, siendo asimismo la mejor manera de redimirnos, en suma ${ }^{8}$. Y, en tercera instancia, hemos de recordar el contexto por tres razones al menos: 1) porque en ningún caso podemos decir que el pasado no dijo lo que decía para su tiempo ${ }^{9}$; 2) porque nuestras abstracciones, con ser todo lo atemporales o transhistóricas que en algún momento se requiera, han de aplicarse siempre a casos concretos, pues sin empiria no hay teoría válida ${ }^{10}$; y 3) porque el contexto es el marco de fondo donde destacan los acontecimientos significativos para nuestro recuerdo, además de ser el espacio

como para la historiografía, declarando que es su "Método de este trabajo: [el] montaje literario. No tengo nada que decir. Sólo que mostrar. No hurtaré nada valioso, ni me apropiaré de ninguna formulación profunda o espiritual. Pero los trapos, los desechos, ésos no los quiero inventariar, sino dejarles alcanzar su derecho de la única manera posible: empleándolos" (no hemos seguido literalmente la traducción de Luis Fernández, ya que hemos añadido en la segunda línea la disyuntiva "o espiritual", y hemos preferido el término "trapos" al de harapos, por tratarse en ambos casos de precisiones más acordes con el conjunto de la obra benjaminiana en su lengua materna).

7. MATE, Reyes: Medianoche en la historia. Comentarios a las tesis de Walter Benjamin "Sobre el concepto de historia". Madrid, Trotta, 2009, p. 237, traduce Eingedenken como recordación por ajustarse más al sentido que Benjamin quiere expresarnos en esta su Tesis XV sobre la historia, significando "un pensar sentido", "es decir, una razón cordial [...] o sapientia cordis que relaciona la memoria con esa razón sentida" y revindicadora.

8. BENJAMIN, Walter: La dialéctica en suspenso. Fragmentos sobre la historia. Santiago de Chile, ARCIS-LOM, 2002, pp. 45-81. El caso de Auschwitz, señero representante a su vez del Holocausto (shoá), es un cercano y doliente ejemplo de qué hemos de recordar para poderlo enmendar en la medida de lo posible; no cometer los mismos errores y reconocer nuestra parte de culpa (dado el caso), satisfacer a las víctimas, tratar de perdonar y reconciliar, crear las condiciones y disposiciones necesarias para que no se perpetúen o reproduzcan horrores pasados... en definitiva: hacer justicia como primordial tarea de todos, siendo aquí la contribución de los historiadores del todo inexcusable, revalorizando cuanto haga falta con nuestro discurso el topos de la historia como magistra vitae sin importarnos su pretendido descrédito (recogido, entre otros, por KOSELLECK, Reinhart: Futuro pasado. Para una semántica de los tiempos históricos. Barcelona, Paidós, 1993, pp. 41-66 y KULA, Witold: Problemas y métodos de la historia económica. Barcelona, Península, 1977, pp. 591-594).

9. SKINNER, Quentin: "Significado y comprensión en la Historia de las Ideas" y passim, en BOCARDO, Enrique (ed.): El giro contextual. Cinco ensayos de Quentin Skinner, y seis comentarios. Madrid, Tecnos, 2007, pp. 63-108 y passim infra (cita en p. 89), quien asevera "que no se puede decir que ningún agente haya querido decir o conseguir algo sobre lo que nunca haya querido aceptar como una descripción correcta de lo que haya querido decir o lograr".

10. Así, "el contexto mismo se puede utilizar como una especie de tribunal de apelación para evaluar la relativa plausibilidad de las adscripciones incompatibles de intencionalidad", planteamiento e hipótesis (SKINNER, Quentin: Significado y comprensión..., op. cit., p. 101). 
de contraste en las complementariedades ${ }^{11}$ de la permanencia y el cambio ${ }^{12}$, el individuo y la sociedad ${ }^{13}$, lo Absoluto y lo Relativo ${ }^{14}$, etcétera.

Hecho este inciso, colegiremos cómo la historia de Los hijos del capitán Grant ${ }^{15}$, al decir de Heller: "ilustra todo lo que tratan la historiografía y la filosofía de la historia"16; la historiación, pues, como conocimiento del pasado de los hombres en sociedad ${ }^{17}$, se apoya de modo natural en la filosofía, especialmente en cuanto ésta nos enseña sobre cómo conocer. La primera distinción heIleriana incide en distinguir algo archisabido, pero muy polemizado también: el carácter científico de la cliología; despachado este problema de antemano ya por Herodoto, y así lo consigna nuestra filósofo, concebía aquél "la historiografía como episteme, esto es, como saber científico, en contraposición a la simple opinión (doxa)"18. No nos vamos a extender más en este asunto por ahora, emplazándolo al tercer epígrafe de este artículo, yendo por delante que Heller discierne muy bien el quid al diferenciar entre el "saber" cotidiano y el propio de la ciencia; este último, la episteme, está normativizado ${ }^{19}$, y evita, o al menos puede y debe hacerlo mediante su proceder crítico y distanciado, todo alejamiento de la verdad y la objetividad ${ }^{20}$ que le son característicos. Para acercarnos científicamente a nuestro conocimiento del pasado es necesario, además, un principio general de selección; siendo éste variado a fortiori, es también coherente porque

11. Correlato historiográfico del Principio de Complementariedad enunciado por Niels Bohr (1927), donde cuánticamente cabe describir los componentes del Universo como corpúsculo y como onda, por su alternante reciprocidad complementaria, de tal modo que cada análisis proporciona una información carente en el otro. Vid. BOHR, Niels: Physique atomique et connaissance humaine. París, Gonthier, 1961.

12. HOBSBAWM, Eric: Sobre la historia. Barcelona, Crítica, 2002, pp. 26-37, 43-45 y passim.

13. ESCANDELL, Bartolomé: Teoría del Discurso Historiográfico. Hacia una práctica científica consciente de su método. Oviedo, SPUO, 1992, pp. 122-124.

14. STEINER, George: Nostalgia del Absoluto. Madrid, Siruela, 2007.

15. VERNE, Jules: Los hijos del capitán Grant. Madrid, Susaeta, 1996.

16. HELLER, Agnes: Teoría de la Historia. Barcelona, Fontanamara, 2005, p. 71.

17. PEREYRA, Carlos: El sujeto de la historia. Madrid, Alianza, 1984, pp. 89s.

18. HELLER, Agnes: Teoría..., loc. cit.

19. POMIAN, Krzysztof: Sobre la historia. Madrid, Cátedra, 2007, p. 29, nos habla de esos controles científicos, al decir que "una narración se considera histórica cuando hace gala de la intención de someterse a un control de su adecuación a la realidad extratextual pasada de la que habla".

20. HOBSBAWM, Eric: Sobre la..., op. cit., p. 20, es taxativo al declarar la importancia, enorme, radicada en "que los historiadores recuerden la responsabilidad que tienen y que consiste ante todo en permanecer al margen de las pasiones de la política de la identidad incluso si las comparten". En las ciencias "duras" el efecto ideológico discurre, sobre todo, en el sentido de los intentos por adaptar los hechos a las teorías y no al revés, como es de recibo; no pensemos que la comparación entrambos yerros hermenéuticos es baladí, pues con desechar su analogía cometeríamos un error de paralaje, al tomar nuestra "medida" desde un punto de vista mal posicionado para realizar dicha estimación. 
no está exento de unidad. Dicha compacidad la suministran los hechos relevantes a los que aludíamos antes, y es una relevancia que hay que entenderla en su peculiar naturaleza, esto es: graduada. El grado se desprende del lógico "juego de escalas" 21, donde en una escala de espacio regional, local o biográfico destacarán una serie de acontecimientos máximos que, en una escala espacial mayor (nacional, continental, mundial), serán incluso nimios, y lo mismo sucede con los otros tercios de la combinatoria: el tiempo, en el cual no serán igualmente considerables unos hechos que otros, pues la presencia y prestancia de éstos depende del lapso temporal elegido para nuestro estudio 22 ; y también en el trasunto o escala temática, en el cual tenemos desde la pequeñez de unidades analíticas como el cuerpo, los precios o la actitud ante la muerte, hasta los "mayorazgos" de las cuerdas ${ }^{23}$ o los territorios (socializaciones, religiones, climas). Esta cláusula finalista, propia de la liminalidad ${ }^{24}$ de nuestra disciplina por mor de su adecuación al objeto que estudia, no presenta mayor dificultad que la de su asunción; así, la investigación de un objeto móvil, cambiante, se fija en sus estadios lo mismo que en sus variaciones, puesto que si algo cambia es porque tenía una permanencia anterior, donde: "El cambio es una sucesión de diferencias en el tiempo en una identidad persistente" ${ }^{\prime 25}$. En el caso de la novela de Verne, las escalas manejadas son pequeñas: biográfica en cuanto a su espa-

21. CARDOSO, Ciro F. S. y PÉREZ BRIGNOLI, Héctor: Los métodos de la historia. Introducción a los problemas, métodos y técnicas de la historia demográfica, económica y social. Barcelona, Crítica, 1976; GUMILEV, Lev N.: La búsqueda de un reino imaginario. Barcelona, Crítica, 1994; KOCKA, Jürgen: Historia social y conciencia histórica. Madrid, Marcial Pons, 2002, pp. 43-104; MARAVALL, José A.: Teoría del saber histórico. Pamplona, Urgoiti, 2007, pp. 69-192; REVEL, Jacques (dir.): Jeux d'échelles. La microanalyse à l'expérience. París, EHEESSGallimard-Seuil, 1996; y TILLY, Charles: Grandes estructuras, procesos amplios, comparaciones enormes. Madrid, Alianza, 1991; entre otros autores.

22. Aquí, como lo remarca HELLER, Agnes: Teoría..., op. cit., p. 73, la "historiografía escoge temas que pueden ser reconstruidos y entendidos con la perspectiva de un final (relativo)", pues "la historia es un proceso en curso, y por lo tanto, incompleto" (HALPERIN DONGHI, Tulio: El espejo de la historia. Problemas argentinos y perspectivas latinoamericanas. Buenos Aires, Sudamericana, 1987, p. 284).

23. En número de cinco, son los ámbitos más básicos en los que cabe dividir toda formación social: "medioambiente, economía, política, cultura y biología", según Mario Bunge (citado en BARREDA, Armando: La historia como sistema adaptativo. Cibernética e Historia. Lima, UIGV, 2007, p. 173).

24. ZELLINI, Paolo: Breve historia del infinito. Madrid, Siruela, 1980. Un cumplido resumen, que seguimos, es la acertada fórmula que reza: "La dialéctica entre dos principios opuestos, el del límite [...] y el de lo ilimitado [...], define una dialéctica de las cosas que no puede entenderse sino como duplicidad temporal" y espacial; formulación debida a VALENCIA, Guadalupe: Entre cronos y kairós. Las formas del tiempo sociohistórico. Barcelona, Anthropos, 2007, p. 133.

25. NISBET, Robert: "Introducción: El problema del cambio social", en NISBET, Robert (comp.): Cambio social. Madrid, Alianza, 1979, pp. 12-51 (cita en p. 12 -en cursivas en el original-). 
cio, de apenas dos años en cuanto a su tiempo y muy puntual (un naufragio) en cuanto a su trasunto; aquí, las relevancias están dadas y son tres: la desaparición del capitán Henry Grant en el mar, su críptico destino (la isla Tabor) y su familia, siendo todo lo demás (el contexto, otros sucesos, otras personas) tan necesario como secundario (en el sentido de no ser hechos relevantes). Si aumentamos la escala, la tarea se multiplica a la par, e incluso puede que en más de un ocasión desconozcamos algunos hechos relevantes. Pongamos por caso que ascendemos hasta la escala espacial de nacionalismo (Escocia), y hasta la escala temporal de un siglo (el XIX), dejando intacto el mismo trasunto de los naufragios para mejor homologar la comparación proporcional con el caso anterior; ahora, el naufragio del Britanny y cuanto con él se relaciona (capitán Grant y familia) pierde toda primacía al ser un suceso más, de los tantos igualmente penosos, acaecidos a la "flota" escocesa y, aún en el supuesto de fijarse especialmente en él algún historiador, pasa a ser a lo sumo un caso ejemplar, compartiendo su protagonismo con una nutrida cohorte de otros hechos no menos destacados. Por supuesto, en la escritura de la historia pueden, y es recomendable, combinarse las escalas, pero en cualquier caso lo que el historiador hace no es crear importancias sino descubrirlas; lo que hemos expuesto es un ejemplo de cómo varían los predominios per se, dependiendo de la escala de observación y no del observador, quien se aplica al análisis de su objeto tal como éste se le presenta desde la perspectiva asumida. No pensemos que este proceder es exclusivo de las Ciencias Humanas y Sociales, puesto que en Física tenemos otro tanto cuando, por poner un ejemplo, se estudian o la fuerza de la gravedad en la Tierra o la gravitación universal; al igual que en el estudio histórico, los resaltes serán unos en lo "micro" y otros en lo "macro", sin que ello suponga olvidar en el primer caso los presupuestos más generales ni tampoco en el segundo las implicaciones más particulares. En suma, lo visto no merma que hoy concibamos la cliología "como el producto final de una pluralidad de agentes históricos (hombres, medio natural, grupos y relaciones sociales, formas organizativas de la vida colectiva o instituciones, sistemas de ideas y creencias, etc.) articulados unitariamente en un vasto conjunto de interrelaciones" 26 ; de ello se desprende que no hemos pretendido agotar lo relativo a los "hechos históricos", más volveremos sobre los tales en el próximo apartado. Cerrando este punto, tenemos una situación análoga, con el comentario helleriano al hallazgo de la primera pista del paradero del capitán Grant; la tripulación del Duncan encuentra, por casualidad, el mensaje del Britanny en el estómago de un tiburón (mensaje embotellado, trilingüe y muy deteriorado, casi ilegible), empero -siempre según Heller-, aunque la "botella ya estaba a bordo del [barco,] mientras se la tomó por un pedazo de roca o una bala de cañón no era un mensaje, ni siquiera un rastro de mensaje. Se convirtió en tal rastro (de mensaje) cuando se la identificó

26. ESCANDELL, Bartolomé: Teoría del Discurso..., op. cit., p. 139 (hemos suprimido las cursivas del original). 
como botella"27. El argumento no puede ser más constructivista además de falaz; el susodicho mensaje en la botella siempre ha sido un mensaje desde su concepción (y mientras no se destruya sin remedio ${ }^{28}$ ), oficiando su descubrimiento como el traslado a un plano de entendimiento entre otros. Dicho traslado intelectivo es el primer paso en toda investigación, el cual, de ser aprovechado científicamente irá rindiendo sus frutos cognitivos. Por esto mismo, defendemos que la interpolación "constructiva" del historiador, como la de cualquier otro científico, sólo debe realizarse a partir del descubrimiento de lo dado y nunca a la inversa. El topos de la más antigua de las exclamaciones "científicas": ¡Eureka!, recobra de esta guisa todo su evocativo valor.

Tampoco estamos de acuerdo con la distinción entre el pasado de nuestro presente y el pasado histórico, pues no es cierto que en "el transcurso de la Segunda Guerra Mundial, nadie hubiera podido escribir un libro de historia sobre una batalla que hubiera tenido lugar el día anterior", siendo que "todas las historias del pasado de nuestro presente son crónicas de algún tipo (orales o escritas)" 29 . Sin entrar en mayores honduras, el pasado para la historiografía es, precisamente, retroceder desde nuestro día anterior hasta la concepción del primer hombre; otra cosa es la información disponible para historiar lo sucedido justo ayer, información que en nuestros "letrados" tiempos aumentará previsiblemente con el paso del calendario, y siempre que se vaya conservando además. Por otro lado, la crónica es un ejercicio preparatorio, una relación de hechos aportados para su historiación posterior ${ }^{30}$, es decir: "una descripción exacta (sic) de lo sucedido, [...] una narración pura de los acontecimientos pasados"; ahora bien, cuando se va "más allá de esa pura narración y [se] pretend[e] no solamente decir lo que sucedió, sino también (de algún modo) explicarlo", dicha "clase de narración [...] se puede describir como "significativa», en vez de "pura»"31. "Así pues, las cró-

27. HELLER, Agnes: Teoría..., op. cit., p. 74. La calidad deteriorada del mensaje, además de conferir un decisivo plus de intriga a la trama de la novela, es figura paradigmática de las "carencias" informativas presentes en todos los "mensajes" del pasado; incluso en el mejor de los casos, ningún documento -o grupo de ellos- puede "contestar" todas las preguntas que se le formulan. Es más, ni siquiera la documentación generada en y para "nuestro hoy" puede contestar, por extensa y completa que sea, todo lo relativo a dicha actualidad en curso.

28. En su descargo, esta salvedad también la recoge la misma Heller en la página siguiente (p. 75); por otra parte, es de Perogrullo que ni siquiera la destrucción del mensaje anula su existencia anterior.

29. Íd., p. 73.

30. Esta era la crítica de Cicerón a los Commentarii de César, considerándola "como una obra importante, aunque [los susodichos] no eran precisamente la obra histórica que la literatura romana necesitaba, sino que venían a ser una especie de acarreo de materiales, para poder algún día un historiador de auténtico fuste escribir las gestas de César" (citado por MARINER, Sebastián (dir.): Lengua Latina I. Madrid, UNED, 1997, p. 500).

31. WALSH, William H.: An Introduction to Philosophy of History. Londres, HUL, 1951, p. 31. 
nicas serían puras narraciones; y la auténtica historia se expresaría en las narraciones significativas" ${ }^{\prime 2}$. Entonces, ¿qué le impediría a un historiador narrar significativamente un evento dado, aunque fuese al día siguiente de haber ocurrido? Una buena "situación" relativa al suceso ayudaría, claro, pero su carencia no es un impedimento, siendo que no otra cosa ha vuelto del revés la historiografía respecto de sus orígenes (la cercanía de Herodoto a lo que él estudiaba fue todo un paradigma, y por siglos); en verdad, esta actualidad es un requisito para un corresponsal, para el escritor de una crónica periodística, entretanto que ningún libro de historia se escribe en un día. Aunque se comience a escribir el día después del evento, hay un buen margen, un largo "tiempo extra", para recabar más información, y por tanto posibilitar mayor significación a lo historiado.

Bien que reservemos la orientación al pasado para la historiografía, y bien que hagamos lo propio con el presente y el futuro para la filosofía de la historia ${ }^{33}$, ya decíamos que lo deseable es la conjunción de ambas y para ambas; así, la aparición del personaje Jacques Paganel en el Duncan, que Heller identifica como el filósofo de la historia, ayuda a recomponer los datos hasta entonces disponibles (sin aportar nuevos ${ }^{34}$ ) y a reformular otras teorías, pues la sostenida por los tripulantes y la familia del capitán Grant (que serían los historiadores) había resultado ser errónea; falsa teoría donde, en principio, "todo encajaba, aparentemente; todo indicaba que el mensaje se había leído correctamente" 35 a pesar de su fragmentario mal estado. De cualquier modo, las teorías del filósofo abocan al mismo decepcionante resultado, pues por más que "a la luz de [cada] nueva teoría [t]odo encajaba otra vez" ${ }^{\prime 36}$, no encontraron al capitán en ninguno de los destinos deducidos. Una vez más, sólo el descubrimiento casual logra coronar en éxito. Empero:

Hay épocas (como la nuestra) en las que el Duncan emprende la travesía para encontrar la botella que pueda contener los mensajes que andamos buscando. [...] La disponibilidad hacia un mensaje en particular constituye la característica general de la conciencia histórica. El primer paso que da la historiografía en cuanto saber científico es descifrar el mensaje que nos da el rastro, o, si no, buscar rastros que nos Ileven a mensajes que leer. Tal proceder tiene que ser metódico y crítico ${ }^{37}$.

32. DANTO, Arthur C.: Historia y narración. Barcelona, Paidós, 1989, p. 61.

33. HELLER, Agnes: Teoría..., op. cit., 78ss.

34. Este prurito, recalcado por Heller, no sería un requisito vinculante, y un buen ejemplo lo constituyen las muchas obras historiográficas de Michel Foucault; por otro lado, también podría aducirse que, en tales casos, el filósofo estaría "ejerciendo" como historiador.

35. HELLER, Agnes: Teoría..., op. cit., p. 70.

36. Íd., p. 71.

37. Íd., p. 75. 
Es decir, la suerte hay que buscarla con método; y con más ahínco, si cabe, tras su primera "sonrisa" (la botella en el tiburón). Entonces, la presencia de los hijos del capitán Grant, como añadidura del interés particular a la empresa "historiadora", también reorienta el trabajo historiográfico hacia el presente y el futuro, como hace la filosofía de la historia ${ }^{38}$; este interés podría calificarse de ideológico si sus actuaciones fuesen torticeras ${ }^{39}$, mas, como no es el caso, vemos que su intervención plasma el alimón "cliología-filosofía de la historia" ya aludido.

La comprensión permite, ergo, la explicación (interpretación), pero no todas las interpretaciones son igualmente válidas; de entre las teorías manejadas en el Duncan, la "de Nueva Zelanda", con ser errónea, es la más cercana al verdadero destino del capitán Grant ${ }^{40}$. Los datos no lo son todo, y así: "la cifra y la medida [no son] el objeto final de la investigación histórica. Son, simplemente, datos brutos, elementos de los que hay que partir para proceder a la tarea más compleja de la interpretación global" 41 ; dicha complejidad se va haciendo inteligible con las su-

38. Íd., p. 79, pues, según Heller, "La autobiografía de los pueblos y de la humanidad está escrita tanto por la historiografía como por la filosofía de la historia. La primera nos hace recordar cosas que se han olvidado; la segunda modifica nuestras vidas, o, cuando menos, nuestra actitud frente a ella reorganizando todo lo que se ha recordado. La primera no pretende jamás modificar nuestras vidas; la segunda no pretende jamás hacernos recordar lo que se ha olvidado. [...] El objeto de la historiografía es el pasado, y [el] objeto de la filosofía de la historia es el pasado, el presente y el futuro en el presente, pero se ocupa del presente desde el punto de vista del futuro"; con todo, la división es demasiado tajante, ya que cualquier actividad humana es proyectiva, y tampoco podemos negar las dimensiones ética y moral a la cliología.

39. Íd., p. 71, donde Heller señala cómo, en "tal proceder, la curiosidad se mezclaba con la implicación". Empero, también defiende nuestra filósofo que en "la historiografía [...] la aplicación pragmática del saber se excluye por principio" (p. 72); cabe entender "interés pragmático" como lo hace Habermas, es decir, para nuestro caso, toda vez que "se usa la historiografía como instrumento para la realización de algún fin social concreto, o para la realización de alguna acción dada" (n. 12 -p. 275-).

40. Para más inri, en lo que resulta toda una ironía literaria, la isla Tabor -o Arrecife María Teresa- parece no ser más que una isla fantasma. "Descubierta" el 16-XI-1843 por Asaph P. Taber (apodado "Tabor"), capitán del ballenero Maria Theresa, las vacilaciones de su cuaderno de bitácora (ora habla de "rompiente costera" -breacker-, ora de "surtidor de una baIlena"-breacher-) refuerzan el hecho de que a día de hoy esté considerada como dudosa su existencia; ni en las coordenadas iniciales, ni en las propuestas años más tarde se la ha podido identificar, pese a lo cual sigue figurando en las cartografías.

41. FONTANA, Josep: "Presentación", en CARDOSO, Ciro F. S. y PÉREZ BRIGNOLI, Héctor: Los métodos..., op. cit., pp. 7-9 (cita en p. 8). Esta cristalización global es la que defiende, en su tesis XVII, BENJAMIN, Walter: La dialéctica..., op. cit., p. 64, diciendo que: si se "aborda un objeto histórico única y solamente cuando éste se [nos] presenta como mónada", entonces el historiador puede captar "esa oportunidad con el fin de hacer saltar una determinada época del curso homogéneo de la historia; y una determinada vida, de una época; y una determinada obra, de entre toda la actividad laboral de una vida. La ventaja de este procedimiento consiste en que la actividad laboral de toda una vida está guardada y conservada en la obra; y toda una 
cesivas teorizaciones ("mientras el Duncan zarpe hacia los océanos del pasado"42), donde "lo que legitima y explica el presente [...] es [...] el pasado considerado como proceso de conversión en el presente [, ya] que la comprensión a posteriori es la forma más convincente que adopta la sabiduría del historiador"43. Esta apreciación, ya postulada por Ortega y Gasset, no marca cuánto tiempo después podremos encontrar una solución, simplemente indica que cabe esperarla; por tanto, siendo que a menudo el "pasado histórico no es lo que está olvidado, sino lo que puede ser recordado", podemos ver que los "historiadores son [como] los psicoanalistas de la especie humana en cuanto transforman lo que está olvidado en objeto de recuerdo" 44 . En suma: propensión, recordación, información, estudio y serendipia -ésta última no sin reservas ${ }^{45}$ - es lo que necesitaríamos para historiar, con "la teoría [...] como idea práctica reguladora de [nuestra] acción" $46 ;$ y, todo ello, en el marco de la "historiografía [, la cual] es una especie de psicodrama en donde el interrogador se ve obligado a adoptar la posición de aquellos a los que quiere entender"47. Finalmente, la conclusión helleriana es desazonadora, dado que "si en lugar de viajar por el espacio, lo hacemos a través del tiempo, nunca podremos encontrar al capitán Grant con vida. Nadie nos va a decir qué sucedió realmente y cómo. No hay final feliz, porque no hay, en absoluto, ningún final"48.

época, en la vida; y el decurso completo de la historia, en la época. El fruto nutritivo de lo que se puede comprender históricamente tiene en su interior, cual semilla preciosa aunque insípida, al tiempo" (no hemos seguido exactamente la traducción de Pablo Oyarzún, porque, al ser demasiado literal, el párrafo resultaba farragoso a causa de muchas de sus frases); asimismo, el concepto benjaminiano de mónada es posibilitado por el escrute en symploké, es decir, en todos los sentidos (vid. el final del II $2^{\circ}$ y la "quinta cuestión" del epígrafe III), y se relaciona también con lo-no-dicho, con lo que no-llegó-a-ser, con la-cápsula-del-tiempo, con la recordación y con la oportunidad-revolucionaria-redentora en la historia, que son otros cinco topoi fundamentales en el pensamiento de Benjamin.

42. HELLER, Agnes: Teoría..., op. cit., p. 71.

43. HOBSBAWM, Eric: Sobre la..., op. cit., p. 31.

44. HELLER, Agnes: Teoría..., op. cit., p. 77.

45. "Serendipia" es el término que castellaniza el vocablo inglés serendipity, con el que se significa el "descubrimiento o hallazgo afortunado e inesperado"; un posible sinónimo es la voz española "chiripa", aunque ésta connota un matiz festivo añadido y su uso es coloquial. De cualquier modo, criticamos el abuso de atribuir a la casualidad más papel del que puede tener, de ahí nuestras reservas; ergo, incluso en las contadas ocasiones en que los descubrimientos fortuitos no surgen de la labor metódica, ésta es fundamental, pues, si falta, incluso un hallazgo importante pasará desapercibido las más de las veces, al no saber comprender ni valorar el acance de su potencial cognitivo.

46. HELLER, Agnes: Teoría..., op. cit., p. 78.

47. Íd., p. 80.

48. Íd., p. 71. Tampoco es preceptiva la disyunción espacio/tiempo propuesta por Heller, desmontada al menos desde Einstein (cuando hablaba del espaciotiempo), pues "no se trata [...] de causalidad del suelo o del medio. El espacio de la historialidad es en principio un espacio simbólico, una superficie de inscripción del tiempo como productor de sentido" (RANCIÈRE, Jacques: Los nombres de la historia. Una poética del saber. Buenos Aires, Nueva Visión, 1993, p. 102). 


\section{El Libro de razón, "de" Michel Houellebecq}

El desalentador final del capitán Grant -según Heller-, al que no podríamos ver con vida, es el punto de partida feliz del Libro de razón ${ }^{49}$, pues éste nos recuerda que los personajes nunca mueren del todo; además, no sólo no mueren al quedar conservados en las novelas y en sus lectores, lo cual ya es un revenant importante, sino que no acaban de morir porque, a pesar de no ver nosotros al capitán Grant con vida, otros sí lo han visto... y lo han contado. La figura del testigo es así el ingrediente documental más importante, por más que Langlois y Seignobos pugnaron para minimizarla ${ }^{50}$; dicho descrédito parte de un error inicial, al entender demasiadas veces al testigo como intruso cognitivo, en vez de tomarlo como una parte activa y activadora de ese pasado que pretendemos estudiar ${ }^{51}$. Al escribir historia, procedemos como con "una novela obligada a que todos los hechos relatados, todos los textos citados fueran exactos" ${ }^{\prime 2}$; así, al igual que apuntábamos el auxilio de la filosofía de la historia en cuanto al cómo conocer, la literatura es nuestra mejor ayuda en cuanto a qué conocer. Muy bien expresa ésto Certeau, comentando el Moisés de Freud ${ }^{53}$ :

En efecto, el relato es la totalización imposible. Se encarga de la relación de lo «científico» con su rechazado. Una «razón» (una coherencia, el establecimiento de un campo) no deja de estar unida al desecho que ella misma crea al constituirse. Uno y otro -el ocupante y el que regresa- actúan en el mismo texto: la teoría presente se encuentra con todo lo inasimilable que viene del pasado bajo la forma de una exterioridad colocada en un texto. Y éste tiene que ser un relato - una «historia» que se cuenta-. Este efecto no-

49. Dividido actualmente en tres trabajos, a partir de un opúsculo manuscrito de treinta páginas (1936) que los tenía como capítulos: "El íncubo profesional", "Algunas notas sobre ficción interplanetaria" y "El libro de las ideas", están recogidos en LOVECRAFT, Howard P.: EI horror sobrenatural en la literatura y otros escritos. Madrid, Edaf, 2002, pp. 35-39, 51-60 y 235263.

50. LANGLOIS, Charles V. y SEIGNOBOS, Charles: Introducción a los estudios históricos. Alicante, PUA, 2009, p. 61, inquieren: "iy en el caso de acontecimientos remotos, cuyos testigos habían desaparecido tiempo atrás, y de los que la tradición oral no había guardado memoria alguna [, cómo procederíamos] ?"; la respuesta es más sencilla de lo que parece, pues no tenían en cuenta los citados autores que todo documento es producto de testigos.

51. DROYSEN, Johann G.: Histórica. Lecciones sobre la enciclopedia y metodología de la Historia. Barcelona, Alfa, 1983, pp. 88s, clarifica que "no en el detalle y en la visibilidad del detalle se encuentra la verdad de las cosas [, pues] no son los testigos de vista y oído quienes garantizan la verdad de las cosas; basta con que reproduzcan correctamente aquello que, desde su punto de vista, había que oír y ver". De este modo, los testigos inanimados o inhumanos (obras de los hombres, naturaleza afectada por nosotros y naturaleza interactuada con nosotros) quedan incluidos en la testificación.

52. HOUELLEBECQ, Michel: H. P. Lovecraft. Contra el mundo, contra la vida. Madrid, Siruela, 2006, pp. 9s.

53. CERTEAU, Michel de: La escritura de la historia. México, UIA-ITESO, 2006, pp. 333s. 
velesco nos indica la relación de dos opositores en la misma posición, de un modo que es todavía el de la yuxtaposición (neben), pero que ya comienza a ser el de la crono-logización (nach). Es el equivalente historiográfico del Moisés egipcio: la ciencia ficción es la ley de la historia.

Vamos a comentar esta cita, por sus muchas implicaciones para la teoría historiográfica. ¿Por qué dice Certeau "ciencia ficción"? Porque, evidentemente, las teorías, los conceptos, las abstracciones son ficticios, ya que no se encuentran como tales en la naturaleza; y, como son ficciones elaboradas por los científicos, empleadas precisamente para poder explicar la naturaleza o realidad, de ahí que sean también "ciencia". Otro punto importante es el de los modos temporales, pues la yuxtaposición, como el cúmulo de adjetivos y adverbios "muy sonoros" en la obra de Lovecraft ${ }^{54}$, además de caracterizar la crónica, en su versión más austera, también juega su papel en el discurso historiográfico: la evocación ${ }^{55}$ y la comparación ${ }^{56}$; y lo mismo tenemos con la cronología, donde Lovecraft entiende que si "entidades separadas de nosotros por cientos de millones de años vienen a manifestarse en nuestra historia humana, es importante datar con precisión los momentos de sus apariciones", las cuales son "puntos de ruptura [que] permiten la irrupción de lo indecible ${ }^{\prime \prime 57}$. Esto no-dicho, que no se puede decir porque no conservamos memoria de ello, como las citadas lagunas del "mensaje" mandado por el capitán Grant-lagunas extensibles a todo documento-, lo rellena la historiografía; así: "El historiador efectúa interpolaciones (complementación de los vacíos en los documentos o del vacío en las representaciones que existen constantemente «entre» determinados documentos). En la mayoría de los casos, las realiza partiendo del así Ilamado conocimiento general del objeto" o caché58. "Se trata, por tanto, de que conozca lo mejor posible ese objeto" 59 . Después, "la relación de dos opositores en la misma posición" nos habla, también, de la figura que llamamos "contrapuesto"; la aclaración que nos brinda Elias, al discernir cómo "la tendencia habitual de nuestra época [es la] de apreciar diferencias como oposiciones" ${ }^{\prime 6}$, encierra la clave de nuestro concepto, siendo un ejemplo el de las irracionalidades ínsitas de la racio-

54. HOUELLEBECQ, Michel: H. P. Lovecraft..., op. cit., p. 82, señala que "nadie se ha atrevido jamás a imitar esos párrafos en los que se pierde toda contención estilística, en los que adjetivos y adverbios se acumulan hasta la exasperación".

55. La cumbre del tinte evocador la tenemos en Michelet, mas el "exceso «romántico» de Michelet no es sino el exceso de la fundación, del orden simbólico que hace posible el desciframiento de una historia más sobria" (RANCIÈRE, Jacques: Los nombres..., op. cit., p. 75).

56. HOUELLEBECQ, Michel: H. P. Lovecraft..., op. cit., p. 75, dice, a propósito de un suceso sufrido por un personaje lovecraftiano: "La yuxtaposición de "hace trescientos millones de años» y de "a las once y cuarto» es igualmente típica" de sus fantásticas comparaciones.

57. Íd., p. 73s.

58. Por "caché", en analogía al concepto informático, entendemos el depósito de conocimientos históricos definitivamente asentados, al cual siempre podemos y debemos recurrir para llevar a cabo nuestras investigaciones, trabajos y docencias.

59. KULA, Witold: Problemas y métodos..., op. cit., p. 595. 
nalidad. Y por fin, el desecho, "lo inasimilable que viene del pasado", que es uno de los elementos de la categoría que llamamos excedente, reunido por y en el discurso historiográfico; según Certeau, lo científicamente excluido es el propio objeto de estudio: el pasado, el cual es el referente del texto historiográfico. Cabe precisar, empero, que dicha exclusión recae, solamente, sobre lo no escrito por el historiador a propósito del pasado que trate; más el añadido de contener el presente gran parte del pasado, en los modos más diversos. En la misma categoría excedentaria, tenemos asimismo las derivaciones, los residuos ${ }^{61}$ y los remanentes ${ }^{62}$. Además de las obligadas ausencias, convocadas en el texto cliológico, están asimismo las obliteraciones, los olvidos y, como no, el mencionado lumpen o "vencido de la historia" benjaminiano; en cuanto a las derivaciones, son, como su nombre indica, atribuciones generalmente simbólicas y prestadas (v. gr., la divinización de un monarca), y los residuos, por su parte, lo que queremos creer, o acto de fe aun a sabiendas de su falsedad (v. gr., el sentimiento monárquico desmedido); y por último los remanentes, entendibles como pervivencias de todo tipo en tiempos, modos y lugares inesperados.

Antes de proseguir, una advertencia: El libro de razón lovecraftiano no se presta, o al menos no lo hace de un modo tan meridiano, a metaforizar "lo que tratan la historiografía y la filosofía de la historia" (como sí ocurre con Los hijos del capitán Grant). La principal razón de ello salta a la vista: El libro de razón no es un relato; y, el segundo motivo, actúa de refuerzo, pues Houellebecq no lo comenta con miras historiográficas ni filosóficas (como sí hace Heller). Lo que tenemos de comparable, para nuestros intereses, entre la teórica de Lovecraft y nuestro empeño teorético aparecería como desordenado; aunque quizá no tanto, ya que, siguiendo a Bergson, el desorden (o caos) no es más que otro tipo de orden pero menos familiar63. De este modo:

Lovecraft [...] incluso intentará una primera conceptualización en un opúsculo manuscrito de treinta páginas titulado El libro de razón. En la pri-

60. ELIAS, Norbert: Teoría del Símbolo. Un ensayo de antropología cultural. Barcelona, Península, 2000, p. 34.

61. VEYNE, Paul: "La historia conceptualizante", en GOFF, Jacques le y NORA, Pierre (dirs.): Hacer la historia (vol. I) Nuevos problemas. Barcelona, Laia, 1978, pp. 75-104 (cita en pp. 94-101).

62. DEBRAY, Régis: El arcaísmo posmoderno. Lo religioso en la aldea global. Buenos Aires, Manantial, 1996, p. 59, ilustra cómo "el escalonamiento de las determinaciones internas de las conductas visibles del grupo [hacen] salir a la superficie social los estratos más antiguos, que son, en este concepto, los más activos. La crisis revela a lo más moderno como lo más superficial, que cede y se resquebraja bajo la presión de lo reprimido" o remanente.

63. BERGSON, Henri: La evolución creadora, en Íd.: Obras escogidas. México, Aguilar, 1963, pp. 433-755 (cita en pp. 629s), propone "que hay dos especies de orden y que estos dos órdenes son dos contrarios en el seno de un mismo género. [Así,] la idea de desorden surge en nuestro espíritu cada vez que, buscando una de las dos especies de orden, encontramos la otra". El actual desarrollo de la "caología", la llamada Teoría del Caos, confirma la tesis de Bergson. 
mera parte, muy breve, da consejos generales sobre la forma de escribir un relato (fantástico o no). Después intenta establecer una tipología de los «elementos terroríficos fundamentales que desempeñan un papel útil en el relato de terror». En cuanto a la última parte de la obra, la más larga con mucho, está formada por una serie de observaciones anotadas entre 1919 y 1935, que normalmente no ocupan más de una frase y podrían servir de punto de partida a otros tantos relatos fantásticos" 64 .

Tres partes que resumen, de manera inmejorable, la sinopsis epistemológica de los presupuestos, los marcos y "los medios operatorios [...] de toda investigación científica [:] el inventariado y clasificación de datos, su análisis y la exposición de las conclusiones analíticas [...] sometidas a comprobación"65; así, vemos cómo se simplifica la propuesta anterior, desprendida de la obra de Verne, pues: 1) El primer operador recoge la demarcación del específico campo histórico (el pasado), la propensión, la recordación, la información y el hallazgo fortuito -que no es sino una peculiaridad ínfima en la recolección de datos-; 2) El segundo operador incluye el estudio, la metodología, la categorización y la regulación práctica de nuestra acción cognitiva (o formulación de hipótesis); y 3) El tercer operador es tanto la psicodramática representación historiográfica ("el ponerse en el lugar del otro") como la escritura del historiador, necesariamente entendidas ambas dentro del marco general de la realidad que pretenden elucidar, y para lo cual adviene el auxilio de una teoría del conocimiento histórico (capaz de hacer más asequible dicha gnosis, como veremos en el epígrafe IV).

En la primera de estas operaciones, así como el pasado es nuestro objeto de estudio, el objetivo lovecraftiano es el terror; pasado no exclusivo de los historiadores, al igual que el terror no es solamente de los novelistas, sino que ambos son como "paisajes" de cambiantes descripciones según quien los aborde. En una de sus novelas, Lovecraft muestra esto mismo, pues los "héroes de este largo relato son un equipo de científicos, lo cual permite una interesante variación de puntos de vista; las descripciones de Lake están relacionadas con la fisiología animal, las de Peabody con la geología... HPL se llega a permitir el lujo de incluir en el equipo a un estudiante apasionado por la literatura fantástica"66. Estos "sujetos históricos" son de varios tipos, como veremos hacia el final del artículo, sin menoscabo de que en última instancia se aglutinen en "los hombres en sociedad" (vid. n. 17); empero, otra división de los mismos es la descriptiva, donde en ocasiones se detallarán mucho (el caso extremo son las biografías), mientras que en

64. HOUELLEBECQ, Michel: H. P. Lovecraft..., op. cit., p. 38.

65. ESCANDELL, Bartolomé: Teoría del Discurso..., op. cit., pp. 147 y 137. Nominándolas más específicamente para la historiografía, y bajo la constante comprobación de sus predicados, tenemos tres fases binarias: compilación-descripción, análisis-comprensión y explicación-recreación.

66. HOUELLEBECQ, Michel: H. P. Lovecraft..., op. cit., pp. 68s. 
otras el detalle apenas contará (su culmen es la historia teórica). También aquí Lovecraft nos sirve de ejemplo, aunque en su caso hay un relevo del primer tipo por el segundo ${ }^{67}$ :

Lovecraft no decidió de inmediato poner en escena personajes intercambiables y anodinos. En sus relatos de juventud, se toma el trabajo de describir en cada ocasión a un narrador diferente, con su entorno social, su historia personal e incluso su psicología... [...] Sólo poco a poco llega a reconocer la inutilidad de cualquier psicología diferenciada. Sus personajes apenas la necesitan; les basta un equipamiento sensorial en buen estado. Porque su única función real es percibir.

Después (el manejo de los datos asignables), los consejos generales sobre cómo escribir un relato corresponden, además de a la citada propensión, o voluntad de buscar la información con empeño, al hecho de comprenderla y explicarla ${ }^{68}$ para después exponerla; al hilo del segundo apartado, tenemos que Lovecraft "multiplica los recursos narrativos que refuerzan la impresión de objetividad: artículos de prensa, informes policiales, actas de sociedades científicas..."69 Llama la atención, en cualquier caso, que siendo tan importante el componente narrativo reciba tan poca atención en las universidades españolas; en particular, y sobre todas las demás, denunciamos en lo tocante a nuestra disciplina la gravedad de su carencia ${ }^{70}$. Esto último, no sólo es porque pretendamos una homologación formal de los trabajos historiográficos, sino porque echamos en falta

67. Íd., p. 62. De cualquier modo, lo que más le reprochamos a Lovecraft son su racismo confeso (con su etnocentrismo asociado), su talante reaccionario (el pasado como "mejor" que el presente) y su desdén por "la vida cotidiana" (adiós, pues, a la historia desde abajo). Por otro lado, el vuelco hacia la anonimia por parte de Lovecraft, siendo el componente de lo "anónimo" de importancia crucial en las relaciones sociohistóricas, entra en relación con la tesis de SCHÜTZ, Alfred: El problema de la realidad social. Escritos I. Buenos Aires, Amorrortu, 2003, p. 47 , quien entiende que en "la anonimia completa, se supone que los individuos son intercambiables, y el tipo de curso de acción se refiere a la conducta de «cualquiera» que actúe de la manera definida como típica por la construcción".

68. Max Weber es el pionero de la explicación comprensiva, fecunda como pocas en inspirar otras, además de poseer su propio valor tanto para la sociología como para la historia; así, "una vez que ingresó rutilante en esta última, ya no volvió a salir", como nos informa HERNÁNDEZ SANDIOCA, Elena: Tendencias historiográficas actuales. Escribir historia hoy. Madrid, Akal, 2004, pp. 73s

69. Íd., p. 76. La aspiración de Lovecraft era la de alcanzar la plasmación de "un terror objetivo [; un] terror liberado de cualquier connotación psicológica o humana. Quiere, según sus propias palabras, crear una mitología que «todavía tuviera sentido para las inteligencias compuestas de gases de las nebulosas en espiral»" (p. 72).

70. CASTRO, Javier y MARTÍNEZ, Saúl: "Monólogo. Educación, tradición y comunicación en la historiografía académica española", en IZQUIERDO, Jesús y SÁNCHEZ, Pablo (eds.): El fin de los historiadores. Pensar históricamente en el siglo XXI. Madrid, Siglo XXI, 2008, pp. 227-250. 
una dialéctica que enriquecería al conjunto de historiadores; por otro lado, no se trata de anular la originalidad de cada cual, teniendo en cuenta, "la personalidad de [nuestro] interlocutor." Como Lovecraft, quien "siempre empieza por intentar entender lo que el autor ha querido hacer; y después sólo formula consejos precisos y puntuales, estrictamente adaptados al relato del que está hablando"71. Sobre la citada recordación benjaminiana, donde las injusticias del pasado claman ser escritas, tenemos la aseveración de Lovecraft: "Nunca intento escribir una historia, sino que espero a que una historia pida ser escrita. Cuando empiezo a trabajar deliberadamente en la escritura de un [hecho], el resultado es insulso"72. Volviendo con la tarea de recabar datos, una primaria distinción de los mismos se nos impone: las fuentes y las noticias; aunque hay trabajos actuales que las reconsideran ${ }^{73}$, sigue siendo válida la precaución de Droysen, quien entiende que, además de su implicación, "es claro que allí donde la fuente posterior se muestra como deducida de una anterior, ya no es fuente ${ }^{\prime 74}$. Finalmente, como se desprende de lo dicho, las noticias son el enorme resto de documentos que no entran en la categoría de fuentes.

Con la segunda parte del Libro de razón entramos en la operación analítica, donde a la par que estudiamos los datos reunidos y clasificados vamos pergeñando hipótesis de trabajo y categorizaciones, apoyados en diversas metodologías; con esto, relacionamos dichos datos entre ellos y con otras categorías e informaciones previas, observando sus reiteraciones, su secuenciación, su lógica, sus desarrollos, etcétera, a fin de alcanzar proposiciones generales y particulares acerca de los fenómenos investigados. Así, a Lovecraft le "gusta documentarse sobre cualquier cosa, ya sean los rituales aztecas o la anatomía de los batracios"75, donde la "gradación de paroxismos que constituye la arquitectura de [sus] «grandes textos» [se] alimenta con nuevos materiales", poniendo en práctica "lo que podríamos Ilamar ataque reforzado. Y siente predilección por esa variante que es el ataque teórico"76, pues Lovecraft "clasifica el material, lo trabaja; a veces se entusiasma y escribe la historia sobre la marcha, [mas] en otras ocasiones sólo conserva algunos elementos para insertarlos en una nueva trama"77. Entre otras, emplea "la técnica de la

71. HOUELLEBECQ, Michel: H. P. Lovecraft..., op. cit., pp. 37s.

72. Citado en HOUELLEBECQ, Michel: H. P. Lovecraft..., op. cit., p. 38. La petición lovecraftiana se asemeja a la aprehensión "al vuelo" de Benjamin, reseñada en su tesis V, pues "La verdadera imagen del pretérito pasa fugazmente. Sólo como imagen que relampaguea en el instante de su cognoscibilidad para no ser vista ya más, puede el pretérito ser aferrado"; BENJAMIN, Walter: La dialéctica..., op. cit., p. 50.

73. TOPOLSKI, Jerzy: La storiografia contemporanea. Roma, Editori Riuniti, 1981; en concreto, el capítulo II: "Lo storico e le fonti: tentativo di una caratterizzazione dinamica delle fonti storiche", pp. 37-62.

74. DROYSEN, Johann G.: Histórica. Lecciones sobre... op. cit., p. 80.

75. HOUELLEBECQ, Michel: H. P. Lovecraft..., op. cit., p. 42.

76. Íd., p. 44.

77. Íd., p. 51. 
constricción", donde, "en los lugares que ha elegido, surge un potente chorro, una extraordinaria eflorescencia de imágenes"78; con todo esto, se está figurando la multiplicidad técnica y de métodos de la historiografía (comentada y enumerados en el siguiente epígrafe). Tamaña elaboración, que es toda una arquitectura cognitiva, "gnoseológicamente, se trata siempre de una estructura o sistema orgánico de términos, relaciones y operaciones" ${ }^{\prime 79}$; y con ello:

La arquitectura de H. P. Lovecraft, como la de las grandes catedrales, como la de los templos hindúes, es mucho más que un juego matemático de volúmenes. Está impregnada de principio a fin de la idea de una dramaturgia esencial, de una dramaturgia mítica que da sentido al edificio. Que teatraliza el menor de los espacios, utiliza los recursos de las diferentes artes plásticas, hace confluir en su provecho la magia de los juegos de luz. Es una arquitectura viva, porque se basa en una concepción viva y emocional del mundo ${ }^{80}$.

Finalmente, la "tipología de los elementos terroríficos, fundamentales para el relato fantástico", asume bien su papel analítico, pues cabe entenderla paralela a otras tipologías; de este modo, aunque en el último apartado de nuestro comunicado (el IV) es donde desgranaremos, brevemente, la tipología entera de nuestra teoría, no haremos tampoco, por mor de la obligada brevedad de un artículo, el menudeo de las subdivisiones, aprovechando aquí para ocuparnos de una subdivisión: en este caso la relativa a los "hechos históricos" (tal como avisábamos supra). Ya no es solo cuestión de relevancias "y especiales proyecciones de algunos acontecimientos, sino que [...] los caracteres que definen el «hecho histórico» podrían compendiarse primordialmente en su condición de resultado funcional, su carácter pretérito y su naturaleza dinámica"81, teniendo siempre presente que "lo que la Historia puede darnos a conocer desde su punto de vista, no son hechos de individuos aislados, ni hechos absolutamente individuales, sueltos, sino encadenamientos, conjuntos de hechos, es decir estructuras configuradas de un modo o de otro" ${ }^{82}$. Además de una adición (apuntada al final del párrafo), conviene también reseñar un distingo, entre los "hechos históricos" y los "acontecimientos", sobretodo a la hora de trabajar con ellos; aunque todo acontecimiento es un hecho, "se puede entender por acontecimiento el contexto de sucesos que es experimentado por los contemporáneos como uni-

78. Íd., p. 55.

79. BUENO, Gustavo: "Una definición gnoseológica de las ciencias humanas", dentro del Ciclo de Conferencias: Cuatro lecciones sobre filosofía de la ciencia (la que nos ocupa: 11-V1978), recogidas en el Boletín Informativo de la Fundación Juan March, Madrid, no 73, 1978 (julio-agosto), p. 41.

80. HOUELLEBECQ, Michel: H. P. Lovecraft..., op. cit., p. 59.

81. ESCANDELL, Bartolomé: Teoría del Discurso..., op. cit., p. 141.

82. MARAVALL, José A.: Teoría del saber..., op. cit., p. 54. 
dad de sentido dentro del marco de sucesión cronológica de un antes y un después, y en cuanto puede ser «narrado» por el historiador con categorías de sucesión cronológica". Además, los acontecimientos pueden ser catalogados en el tiempo breve, dado que "no sobrepasan el espacio cronológicamente registrable de la experiencia de los participantes" 83 . Por contra, el hecho histórico puede desbordar a sus contemporáneos, ya que la puntualidad no es su única temporalización posible, pudiéndose extender por generaciones (un ejemplo: el "hecho histórico" del Imperio Romano, que duró varios siglos); a más, aún los hechos históricos ceñidos a los acontecimientos se distinguen de aquéllos, porque el hecho se entiende consumado y el acontecer es su primer paso analítico procesual; y en tercer lugar, si el acontecimiento es percepción del presente y el pasado, el hecho histórico añade la dimensión del futuro, donde aparecen las consecuencias y derivaciones de los acontecimientos. Así, cuando hablamos de "hecho" sin más, de un modo genérico, estamos englobando todos los supuestos, empleando "hecho histórico" y "acontecimiento" para la distinción antedicha; y todavía teníamos pendiente un tercer término, completivo de nuestra lista: "factum", reservado para remarcar la cualidad de "hecho histórico incuestionable" 84 .

La parte conclusiva es el broche, asimismo, del presente epígrafe. Comenzando por la traslocación de "ponernos en el lugar del otro", los apuntes lovecraftianos (222 en total) serían otros tantos intentos de acercarnos a la otredad, pues tratan sobre experiencias, vidas, historias que no son las propias (en este caso: figuradas, pues son obra de la imaginación literaria); para el caso del historiador, es casi lo mismo, con la crucial salvedad de que esas experiencias, esas vidas, son historias ocurridas verdaderamente a gentes de verdad (historias y gentes, incluso, todavía en curso y vivas cuando historiamos partes muy recientes del pasado). La relación ficción-realidad y realidad-ficción es, contra lo que podría suponerse, estrechísima, porque, al igual que la ficción figura la realidad dado que surge de ella, la realidad figura la ficción al proyectarse hacia la misma; los

83. KOSELLECK, Reinhart: "Darstellung, Ereignis und Struktur", citado en HERNÁNDEZ SANDIOCA, Elena: Tendencias historiográficas..., op. cit., p. 189.

84. LAKATOS, Imre: La metodología de los programas de investigación científica. Madrid, Alianza, 1989, p. 13, llama a estos conocimientos indubitables "el «núcleo firme»" de todo programa científico, el cual "está tenazmente protegido contra las refutaciones mediante un gran «cinturón protector» de hipótesis auxiliares. Y, lo que es más importante, el programa de investigación tiene también una heurística, esto es, una poderosa maquinaria para la solución de problemas que $[\ldots]$ asimila las anomalías e incluso las convierte en evidencia positiva". Solamente la aparición de otro programa, más progresivo, o el paso de uno en regresión a la progresión, pueden llevar a la adopción de otro paradigma más adecuado a la porción de realidad estudiada; esto sucede igualmente en la historiografía, aunque con la salvedad de quedar los "programas obsoletos" como "especialidades" menos cultivadas en cualquier caso (esta es la conclusión del trabajo de OLÁBARRI, Ignacio: "La «Nueva Historia», una estructura de larga duración", en ANDRÉS-GALLEGO, José (dir.): New History, Nouvelle Histoire: Hacia una Nueva Historia. Madrid, Actas, 1993, pp. 29-81). 
ejemplos del primer supuesto forman legión, con los tantos y tantos personajes, situaciones e historias de la literatura que nos hablan de personas, aconteceres e historias reales, y lo mismo a la inversa, siendo el caso del simbolismo uno de los más habituales: la Patria, la Bandera, la Fiesta, el Calendario que aglutinan a unas gentes en torno a unas ideas coadyuvantes ${ }^{85}$. En lo que hace a la escritura de la historia, el "estilo de informe científico que utiliza Lovecraft en sus últimos relatos obedece al siguiente principio: cuanto más monstruosos e inconcebibles sean los acontecimientos y entidades descritos, más precisa y clínica ha de ser la descripción" ${ }^{\prime \prime 6}$; es decir, que por más extraño que nos sea el pasado ${ }^{87}$ no hemos de renunciar a una exposición científica, rigurosa, de cuanto vamos conociendo del mismo. Exposición necesariamente sintética, por descontado, independientemente de la extensión que tenga el trabajo historiador, ya que con ser "tan grande la multitud de los hechos históricos, [...] si la historia los pudiera recoger y registrar todos, no habría nadie que pudiera estudiarlos ni conocerlos" ${ }^{\prime 8}$; asimismo, también son operaciones sintéticas "la ordenación de los hechos o composición histórica"89, y las previas elaboraciones de fichas para su postrer desarrollo por el historiador, siendo estas últimas como los mentados apuntes lovecraftianos que le servirían "de punto de partida a tros tantos relatos fantásticos". El marco general de referencia es, huelga decirlo, el "más amplio y comprensivo [habiente, es decir:] el de la composición, estructura y mecánica de la realidad natural"90; reconocimiento que Lovecraft practica con "su demostración de los estrechos vínculos entre las matemáticas trascendentales y ciertas ciencias mágicas de una antigüedad inconcebible, que dan fe de un conocimiento del cosmos muy superior al nuestro" ${ }^{\prime 91}$. Por último, las susodichas anotaciones lovecraftianas vienen a ejercer el papel de los elementos de nuestra teoría ${ }^{92}$ (el sistema-mundo-histórico o paralipómeno, desmenuzado en el epígrafe postrero).

85. Ficciones coadyuvantes son aquellas que asumimos ante situaciones que nos desbordan, a fin de poderlas sobrellevar mediando el expediente de "normalizarlas"; originariamente, BARRECA, Regina: Maridos perfectos... y otros cuentos. Barcelona, Ediciones B, 1995, p. 233, nos recuerda cómo: "La existencia de ese algo o alguien «coadyuvante» fue revelada por los psicólogos que trataban con los allegados de personas alcohólicas y drogadictas. Siempre hay un miembro de la familia que ejerce la función de «coadyuvante»: es el que se encarga de hacer que el hogar funcione y se mantenga estable. Pero cuando el hogar no «funciona» y no es «estable», el coadyuvante crea la ficción, la falsa apariencia, para que la familia pueda ofrecer al mundo exterior una imagen aceptable que le permita mantener su posición social".

86. HOUELLEBECQ, Michel: H. P. Lovecraft..., op. cit., p. 73.

87. Cfr. LOWENTHAL, David: El pasado es un país extraño. Madrid, Akal, 1998.

88. RISCO, Vicente: Elementos de Metodología de la Historia. La Coruña, Nós, 1928, p. 135.

89. Íd., p. 131.

90. ESCANDELL, Bartolomé: Teoría del Discurso..., op. cit., p. 39 (en cursivas en el original).

91. HOUELLEBECQ, Michel: H. P. Lovecraft..., op. cit., p. 71 (las cursivas son nuestras).

92. Este es otro punto de contacto con las tesis de Walter Benjamin, aunque las del filósofo sí están concebidas ex profeso para el estudio de la historia; a mayor abundamiento, las anotaciones de Lovecraft superan los dos centenares, siendo en su mayoría como breves jaculatorias, 


\section{Algunas cuestiones previas a nuestra teoría}

Una de las aportaciones más interesantes, de la teorética manejada por la "Escuela" de Annales, es la de su perspectiva modulada a partir de la excentricidad ${ }^{93}$; en sus obras, desde el libro de Febvre sobre el Franco Condado (1912) hasta hoy, no aparece ya un núcleo conductor de la historia abordada, un punto de fuga del cual partan las líneas maestras de la narratio ${ }^{94}$ que deben recorrer las personalidades centrales, ya que ni siquiera hay personalidades centrales... ¿ O sí las hay? La consideración global, aplicada con tino por los analystes, encubre su nueva quasi centralidad, donde las novedades más importantes residen, en primer lugar, en que desaparecen los acontecimientos entretanto las personalidades manejadas son generalmente colectivas e incluso hasta impersonales ${ }^{95}$; además, la segunda gran novedad estriba en

entretanto las disquisiciones benjaminianas son pensamientos más desarrollados y su número es de diecinueve (empero, la "tesis [decimoctava] no figura en las primeras traducciones castellanas porque tampoco está en las primeras ediciones alemanas. Agamben descubrió en 1981 un texto dactilografiado con [dicha] tesis [,] que se suele señalar [como] XVIIa, para no alterar la numeración de los Gesammelte Schriften (otros [, entre ellos nosotros,] prefieren sin embargo señalarla con el número XVIII, tal y como aparece en el documento T4)". MATE, Reyes: Medianoche en la historia..., op. cit., p. 275, n. 1).

93. Vid. ALONSO MARTOS, Andrés y VÁZQUEZ, Manuel E. (eds.): Periferias. El extremo como término medio. Madrid, Verbum, 2008.

94. ANKERSMIT, Franklin R.: Narrative Logic: A Semantic Analysis of the Historian's Language. Dordrecht-Boston, Martinus Nijhoff, 1983, p. 87, quien emplea este término como el propio para designar la peculiar escritura de la historia; aquí hemos de entender comprendidas diversas especies intertextuales: el texto, el metatexto (CERTEAU, Michel de: La escritura..., op. cit.), el contexto (POCOCK, John G. A.: The Ancient Constitution and the Feudal Law: a study of English Historical Thought in the Seventeenth Century. Cambridge, CU, 1957 y SKINNER, Quentin: Fundamentos del pensamiento político -2 vols.-. México, FCE, 1979), el cotexto (IITRIK, Noé: Historia e imaginación literaria. Las posibilidades de un género. Buenos Aires, Biblos, 1995, pp. 66-70), el hipertexto (DÍAZ BARRADO, Mario P.: Memoria de la palabra. Topología del discurso contemporáneo. Cáceres, UC, 1997) y la "ideoléctica" o conjunto de los lenguajes de los campos sociales, asimismo enfocados especialmente desde su intencionalidad y su acción (uno de sus tipos, la ideopraxia o naturaleza de los "textos de intervención política", es hallazgo de JAUME, Lucien: "El pensamiento en acción: por otra historia de las ideas políticas", en Ayer, Madrid, no 53, 2004, pp. 109-130).

95. RANCIÈRE, Jacques: Los nombres..., op. cit., pp. 9, 28 y 96, quien señala cómo "la revolución histórica quiso justamente revocar la primacía de los acontecimientos y de los nombres propios en beneficio de las largas duraciones y de la vida de los anónimos", donde "las masas [...] se pervierten situándose por fuera de su lugar, abandonando las grandes regularidades de su objetivación para fragmentarse y disolverse en sujetos que hablan, que se relatan y que relatan a los demás", a la par conque dicha revolución opera "el desplazamiento de la fuerza de la historia [sita en el] rey, de su capacidad de ser centro y organizador de [la] historia [, hacia] ese nuevo sujeto Ilamado Mediterráneo". En realidad, como dilucida RICOEUR, Paul: Tiempo y narración (vol. I) Configuración del tiempo en el relato histórico. México, Siglo XXI, 2004, p. 299, en el remitente caso cabe hablar propiamente de "personajes"; es decir: entidades del tipo de las sociedades, las naciones, las mentalidades, los marcos geográficos, que además son "cuasi personajes capaces de guiar el reenvío intencional desde el plano de la historia-ciencia al de la narración, y a través de éste, a los agentes de la acción efectiva". 
que su nucleamiento es decididamente policéntrico, constituyéndose muchos de los otrora márgenes en actuales centros. Cabe, pues, hablar de una centralidad descentrada, desenfocada tanto por el discurso como por el contenido de su narratio o, en otros términos: Annales labora desde una excentricidad ponderada; en cualquier caso, esta desfocalización es muy conveniente, puesto que abre la perspectiva cliológica a un mayor abarcamiento, lo cual redunda en la disminución del eurocentrismo y otros reduccionismos, graves yerros por lo general asociados a dicha estrechez de miras. Por descontado, nosotros entendemos que centralidad y marginalidad son enfoques claramente complementarios.

Como en la tabla periódica de los elementos químicos de Mendeleiev y Meyer, los elementos históricos fijos de la teoría cliológica ofrecen un lugar a los invariables humanos; sus agrupaciones, bloques, números, pondus, valencias, masas, orbitales, comportamientos y demás idiosincrasias de dichos elementos están siempre ahí, a modo de guías representantes de la generalidad, sin menoscabo de que la particularidad siempre habrá que estudiarla en cada caso. En esta línea, la propuesta de una nomenclatura común a las ciencias naturales y a las humanas es pertinente, pues con ser la cliología

una ciencia idiográfica [...], es decir, dedicada al estudio de lo singular, único e irrepetible, en la Historia se presentan fenómenos comunes a muchas culturas, tal es el caso, por ejemplo, del culto al Sol o las guerras recurrentes. [Así, colegimos cómo] entraña la premisa de que en los fenómenos históricos, independientemente de sus apariencias y diferencias, existe un denominador común, la búsqueda de una respuesta general y no sólo particular ${ }^{96}$.

Con especial prevalencia, dicha nomenclatura adviene factible para la aplicación genérica, porque es la más abstracta, tal como lo preconizó Vico ${ }^{97}$ hace casi tres siglos; la casuística, por contra, demanda en cualquier instancia su jerga exclusiva, igual para las ciencias "duras" que para las "blandas". Debido a esto, es muy injusta la crítica de Durkheim ${ }^{98}$, al negar en 1888 a la entonces Ilamada "historia el rango de ciencia, precisamente porque se ocupaba de lo especial y,

96. GONZÁLEZ BARROSO, Antonio: La historia y la teoría del caos. Un nuevo diálogo con la física. Puebla, BUAP-UAZ, 2005, p. 189.

97. VICO, Giambattista: Principi di scienza nuova d'intorno alla comune natura delle nazioni. Nápoles, 1725, p. 349, donde sentencia que "la historia no puede ser más cierta que cuando aquel que la crea con sus objetos y hechos es también quien la narra [,] como la geometría cuando construye el mundo de la cantidad tomándolo de sus elementos, [ya que] nuestra ciencia crea para sí misma el mundo de las naciones; empero con una realidad aún mayor [para la historia,] pues son instituciones que tienen que ver con asuntos humanos los cuales son más reales que los puntos, líneas y figuras" .

98. Citado por IGGERS, Georg G.: La ciencia histórica en el siglo XX. Las tendencias actuales. Barcelona, Idea Books, 1998, p. 36. 
por ello, no podía llegar a las afirmaciones generales, empíricamente comprobables, que constituían el núcleo de un modo de pensar científico"; en cuanto a esta dicotomía de la particularidad y la generalidad, Todorov aclara que ${ }^{99}$

es verdad que la historia trata de realidades singulares, pero cuando esas mismas realidades son examinadas desde el punto de vista del economista o del sociólogo, del psicólogo o del lingüista, aparecen como la manifestación de leyes generales; recíprocamente, la biología y la física establecen, ciertamente, unas leyes, pero no parten menos de la observación de casos singulares. No podemos decir, finalmente, que unas estudian las cosas y las otras los signos, puesto que los signos también son cosas, y que, al mismo tiempo, lo que creíamos que eran puras cosas, se revelan, a su vez como signos; ¿no se habla hoy en día de un código genético?

Empero, todavía unos años después (1903) de la crítica durkheimiana, y a su sombra, en el artículo «El método histórico y las ciencias sociales» "François Simiand [entendía que] la unión de historia y ciencias sociales era posible a lo sumo en la historia económica"100. Alejados al fin de aquellas controversias vampíricas, siendo además su inicio anterior al ejemplo reseñado, abogamos por una colaboración interdisciplinar sin más jerarquía que la perspectivista, dado que no "hay problemas dominantes y problemas subordinados: todos los problemas son concéntricos"101; en aquel vampirismo unas ciencias pretendían abducir a otras, pues a los "ataques" durkheimianos respondieron los braudelianos en términos similares, como ya había sucedido antes entre los partidarios de cada bandera. Por esto, el objeto abordado por una disciplina ha de partir para su estudio desde esa ciencia, auxiliada cuanto sea necesario por las restantes facultades aunque sin más pretensiones, dado que cada "disciplina puede ayudar a la otra a librarse de una cierta limitación"102.

En esta línea polinuclear, la cliosfera puede entenderse con la famosa metáfora esférica, aplicada para definir a Dios: "una esfera infinita cuyo centro se haIla en todas partes y su circunferencia en ninguna"103; el "centro" está por doquier al serlo cada hombre desde Adán, y su "perímetro" no puede localizarse ni focalizarse mientras viva algún hombre, pues la historia que vivieron, vivimos y vi-

99. TODOROV, Tzvetan: Las morales de la historia. Barcelona, Paidós, 1993, pp. 18s.

100. Nueva cita de IGGERS, Georg G.: La ciencia..., loc. cit. En este texto, asimismo arremete Simiand contra los que él califica como "tres ídolos de la tribu de los historiadores": el de los orígenes, el de la política y el de las individualidades.

101. MERLEAU-PONTY, Maurice: Fenomenología de la percepción. Barcelona, Península, 2000, p. 418.

102. BURKE, Peter: Sociología e historia. Madrid, Alianza, 1987, p. 11.

103. Citada en LUCENTINI, Paolo (ed.): El libro de los veinticuatro filósofos. Madrid, Siruela, 2000, p. 47. 
virán es temporalización protentiva ${ }^{104}$, extensiva e intensiva antes que protención, extensión y tensión temporales. Aunque los historiadores de Annales no lo entendieron así, esta consideración global de lo históricamente estudiado no excluye considerar el paralipómeno como un sistema-mundo-histórico. El término paralipómeno lo empleamos especialmente por dos motivos: uno, por su significado de "crónicas olvidadas", ya que el olvido juega un papel de primer orden en la historia; y el segundo, por su relación con Israel, primero de los pueblos con una marcada conciencia histórica semejante a como hoy la entendemos, de consuno a las diversas consecuencias que de la misma historialidad derivaban los judíos. El prurito de los analystes comienza con su rechazo al concepto "sistema", al interpretarlo como objetivante y cosificador; nosotros, empero, definimos en este caso "sistema" como un "complejo relacional", lo cual satisface las objeciones mentadas. "Mundo" e "histórico" no precisan, en primera instancia, mayores aclaraciones, siendo el utillaje que Ilamamos "estructura" el siguiente concepto cuestionado, máxime tras las superaciones estructuralistas y postestructuralistas; aquí colegimos una confusión en las atribuciones conceptuales, ya que la "organización" es la parte invariante de un sistema, sin que por ello sea la susodicha ningún freno al proceso que se desarrolla desde la misma. La organización es una contextualidad, un núcleo basal, y no un dispositivo mecanicista $^{105}$. Ergo, que lo permanente no excluye lo cambiante, lejos de ser una paradoja, es una evidencia fundamental para toda historiación; con un sencillo ejemplo ilustramos nuestro aserto: el hombre, en su constante reproducción y desarrollo, no ceja de cambiar al advenir nuevos hombres entretanto van muriendo muchos otros, empero todos somos hombres y, todavía más, cada hombre va cambiando a lo largo de su vida sin por ello dejar de ser la misma persona. Muy bien lo expresa Toynbee, al decir que al "fin y al cabo, si un vehículo ha de adelantar por el curso que haya establecido su conductor, tendrán que sostenerlo ruedas que giren monótonamente"106.

No vamos a poder desgranar toda la potencialidad del paralipómeno, como se sobrentiende, dado el escaso espacio de una sección en un artículo; mas daremos a continuación un cumplido resumen del mismo ${ }^{107}$, tras anotar algunas cuestiones previas.

104. La protención es una cierta e indisociable "anticipación" de la siguiente fase a percibir del objeto que estamos percibiendo, apud la fenomenología del tiempo de HUSSERL, Edmund: Lecciones de fenomenología de la conciencia interna del tiempo. Madrid, Trotta, 2002, pp. 73s.

105. Esto mismo es lo defendido por Reinhart Koselleck, en GADAMER, Hans G. y KOSELLECK, Reinhart: Historia y hermenéutica. Barcelona, Paidós-ICE/UAB, 1997, p. 70, cuando define a su "Histórica [como] la doctrina de las condiciones de posibilidad de historias".

106. TOYNBEE, Arnold J.: La civilización puesta a prueba. Buenos Aires, Emecé, 1954, p. 22.

107. El necesario despliegue de toda la teorética implícita en el paralipómeno es una de las partes principales de nuestra tesis doctoral (su título provisional es: La última Edad), todavía en curso. 
La primera cuestión antecedente es la del lenguaje, máxime hoy, porque

tanto la narratología formalista como la semiótica estructural," comadres del giro lingüístico, "más preocupadas por establecer un sistema interrelacional de carácter axiomático indiferente a la realidad extralingüística que por determinar las incidencias tropológicas de dicha estructura acrónica en la coincidencia histórico-efectual, han ignorado [...] la [historialidad] constitutiva de la función narrativa, a saber, la diacronía inherente a la historia contada, el decurso teleológico vinculado a su representación."108

Abundando en esto mismo en muchos de sus trabajos, piensa Ricoeur

que la filosofía tiene la tarea principal de volver a abrir el camino del lenguaje hacia la realidad, en la medida en que las ciencias del lenguaje tienden a distender, si no a abolir, el vínculo entre el signo y la cosa [siendo que] la intención principal del lenguaje [...] consiste en decir algo sobre algo. [...] Tomando como base el acto predicativo, el intentado ${ }^{109}$ del discurso tiene por objeto algo real extralingüístico, su referente. Mientras que el signo sólo remite a otros signos en la inmanencia de un sistema, el discurso se refiere a las cosas. El signo difiere del signo; el discurso se refiere al mundo. La diferencia es semiótica; la referencia, semántica. [E] I discurso [es] la mediación entre el orden de los signos y el de las cosas."110

Efectivamente, la referencialidad es la instancia más básica del lenguaje, pues a partir de la misma tenemos en el habla (y la escritura) la mejor forma de comunicación del conocimiento y, asimismo, la mejor manera de formularlo ${ }^{111} \mathrm{e}$ incluso de adquirirlo; nuestro pensamiento, nuestra reflexión, nuestra memoria se producen y reproducen con el lenguaje, que es uno de los principales sentidos del existir humano -sino el principal de todos-, siendo la mejor prueba de su eficacia la supervivencia hasta hoy de nuestra especie ${ }^{112}$, con sus adelantos y

108. ARANZUEQUE, Gabriel y GABILONDO, Ángel: "Introducción", en RICOEUR, Paul: Historia y narratividad. Barcelona, Paidós, 1999, p. 11.

109. El término "intentado" remite a aquello que el hablante desea o pretende decir, esto es, a la actualidad lingüística de lo que piensa, apud BENVENISTE, Émile: Problemas de lingüística general (vol. II). Madrid, Siglo XXI, 1977, p. 226.

110. RICOEUR, Paul: Historia..., op. cit., pp. 41, 46 y 49.

111. CERTEAU, Michel de: La escritura..., op. cit.

112. ELIAS, Norbert: Teoría del símbolo..., op. cit., p. 115-136 y passim, deja bien sentado que "la comunicación por medio de un lenguaje o, en otras palabras, por medio de símbolos sonoros socialmente regularizados, [permitió] la emancipación simbólica, [esto es:] la emancipación de la acción humana del sometimiento dominante al estímulo del instante presente, [la cual es] un paso importante, muy decisivo sin duda en el camino de la humanidad hacia su posición de especie [...] dominante en la tierra" (pp. 134s). 
adecuaciones humanistas a pesar de conllevar éstos tantas barbaries. El lenguaje nos acerca más a la vida, a la realidad, en mayor medida de lo que al alimón nos abstrae y aleja de dichas vitalidad y realismo, porque "el estudio de la naturaleza sugiere que conocer algo en la mente no deroga su existencia fuera de la mente" 113 .

En orden a este conocimiento, desde el lenguaje elaboramos los conceptos, coligiendo el concepto como una palabra a la cual se le ha adherido "un contexto de experiencia y significado sociopolítico", siendo pues los "conceptos [unos] concentrados de muchos contenidos significativos"114. Aquí vamos a centrarnos sucinta y esquemáticamente en los Ilamados conceptos de segundo orden ${ }^{115}$ o metaconceptos ${ }^{116}$ cliológicos, en concreto los cuatro más lingüísticos: "comprensión, descripción, explicación y narración"; los metaconceptos de "modo, tiempo y espacio", elididos ahora por estar tratados supra e infra, "están presentes en todos los casos, ya que son centrales y están involucrados en cualquier contenido histórico"117. Vamos pues a resumir a continuación las etapas de toda historiación, ya mentadas a propósito de la nota 65; empero, como el cuadro que referimos da pie a diferenciar cuatro tipos de cliología, lo hemos adaptado, pues, en verdad, de lo que cabe hablar es de tres fases en la labor historiadora. Estos pasos, se dan siempre a partir de los datos recogidos en las fuentes, que nos suministran los datos y evidencias, tamizados en el marco general de referencia (contexto) y por la teoría empleada, y así: 1) La descripción, que actúa de compiladora de datos, estaría relacionada con la "crónica, que pretende idealmente lograr una descripción objetiva (o tan objetiva como sea posible) de los acontecimientos y hechos históricos"; 2) La comprensión o empatía, que actúa de analizadora del paso anterior, "pretende entender la perspectiva (mentalidad, filosofía, creencias) de aquellos que vivieron en el pasado"; y 3) La explicación, que recrea el pasado mediante la narración, "tiene como meta explicar el cambio (del tipo que sea: social, económico, político, ideológico, etc.) [, buscando] identificar las causas de los acontecimientos históricos [tanto] intencionales [como] estructurales"118. Resta insistir, para cerrar esta cuestión, que el actual discurso historiográfico integra las tres fases.

113. APPLEBY, Joyce, HUNT, Lynn y JACOB, Margaret: La verdad sobre la historia. Santiago de Chile-Barcelona, Andrés Bello, 1998, p. 233.

114. KOSELLECK, Reinhart: Futuro pasado..., op. cit., p. 117.

115. ASHBY, Rosalyn, DICKINSON, Alaric y LEE, Peter: "Las ideas de los niños sobre la historia", en CARRETERO, Mario y VOSS, James F. (comps.): Aprender y pensar la historia. Buenos Aires, Amorrortu, 2004, 217-248 (cita en p. 218, mas desarrollada en todo el capítulo).

116. LIMÓN, Margarita: "Conceptual change in history", en LIMÓN, Margarita y MASON, Lucia (eds.): Reconsidering Conceptual Change: Issues in Theory and Practice. Dordrecht, Kluwer, 2002, pp. 259-289 (en particular, pp. 263-265, 270, 274-277 y 281).

117. LIMÓN, Margarita: "El fin de la historia en la enseñanza obligatoria", en IZQUIERDO, Jesús y SÁNCHEZ, Pablo (eds.): El fin de los historiadores..., op. cit., pp. 87-111 (cita en p. 92).

118. Íd., pp. 90 s. 
La segunda cuestión gira en torno al concepto de "campo de presencia"119, el cual es una capa más (o aura, si hablásemos desde la metafísica) de las que revisten a las personas: roles, expectativas, ideologías, prestigios, biografías, sufrimientos, creencias, conocimientos, máscaras... Aura, por ende, dispuesta a modo de contenedor de casi todas las restantes, ya que todo lo que nos constituye conforma nuestra historia; bien lo dijo Ortega, al sentenciar "que el hombre no tiene naturaleza, sino que tiene... historia"120, pues "el sentido de nuestro ser es la temporalidad"121. Se desprende de lo dicho que en el campo de presencia la temporalización de la vida humana reviste especial importancia, conformándose así otra capa sobre la susodicha presencial, a la cual podemos denominar "campo de historialidad"122. Merleau-Ponty, por supuesto sólo bajo su rótulo conceptual, lo define como el "momento que paso trabajando con, tras él, el horizonte del día pasado y, delante, el horizonte del atardecer y la noche [en que] tomo contacto con el tiempo, [donde] aprendo a conocer el curso del tiempo"123; dicha temporalización, al ser historializada contribuye a rellenar la siempre expansiva cliosfera, no exenta -claro está- de sus zonas de sombra (los desconocimientos) o materia oscura (por seguir emparentando con la terminología de las "ciencias duras") y de sus zonas de penumbra (los olvidos). Cliosfera que es la suma y más que la suma de todas las historias individuales y colectivas, por más que la conozcamos sesgada, reducida por nuestro -en todo casolimitado conocimiento historiográfico o meramente histórico.

La tercera cuestión es la de los documentos, que al menos desde Febvre ya sabemos incuestionablemente que incluyen un amplísimo espectro de cuanto pueda informarnos sobre el pasado; esta generalidad es susceptible de una segunda gran división"124: "la conocida diferencia entre datos «duros» (precisos, mensurables) y datos «blandos» que son lo contrario"125. Empero, con "demasiada frecuencia los datos blandos son los valiosos y los duros los que son relativamente

119. MERLEAU-PONTY, Maurice: Fenomenología..., op. cit., pp. 418-441.

120. ORTEGA Y GASSET, José: Historia como sistema. Madrid, Revista de Occidente, 1975, p. 61.

121. HEIDEGGER, Martin: Ser y Tiempo. Madrid, Trotta, 2003, p. 348. No hemos seguido fielmente la traducción de Jorge E. Rivera, puesto que sustituimos "del Dasein" por "de nuestro ser" para clarificar la frase, aunque el significado es el mismo; además, preferimos "temporalidad" a "temporeidad", por entender que el primer término se ajusta más a la particular cualidad temporal humana.

122. Este campo es asimismo "un "campo de fuerza»; una serie de formas de organizar el pasado por y para partes interesadas que siempre proceden de algún lugar y con algún objetivo, y que les gustaría llevar[nos] con ell[a]s por sus derroteros", siendo cada uno de nosotros, por supuesto, un constituyente de alguna de tales "partes interesadas" (JENKINS, Keith: Repensar la Historia. Madrid, Siglo XXI, 2009, p. 1).

123. MERLEAU-PONTY, Maurice: Fenomenología..., op. cit., p. 423.

124. La "primera gran división" es la que establece a las fuentes y a las noticias, ya comentada supra.

125. BURKE, Peter: Sociología..., op. cit., p. 45. 
fáciles de obtener", precisamente cuando necesitamos encontrar "datos duros que sirvan de índices fiables de los blandos"126. Con todo, lo crucial es elaborar una tipología flexible, politética, donde "ningún atributo es ni necesario ni suficiente para pertenecer a ese grupo" o categoría detectados, definiéndose así "en función de un conjunto de atributos, de forma que cada entidad posee la mayoría de los atributos y cada atributo es compartido por la mayoría de las entidades"127. Aquí, además, podemos aplicar los conceptos de grupo o categoría para el sentido investigador en general; si lo hacemos así, podremos referirnos también a los conjuntos de datos que conseguimos recopilar sobre un trasunto "equis" del pasado. Ergo, contando con una serie de informaciones, muchas veces sólo reclutadas mediante el Ilamado análisis de encuestas (no exento de indicios en algunos puntos contradictorios), lograremos establecer la interpretación más fiable del suceso en cuestión; asimismo, vía la atención a los aspectos compartidos por la mayoría de estas observaciones del pasado, lo mismo averiguaremos sobre sus alcances y relaciones con otras ocurrencias simultáneas (es decir, trabajaremos con un índice suficiente). De cualquier modo y en razón de esta gran utilidad dativa, no debemos olvidar que "duros o blandos, los datos no nos proporcionarán respuestas a nuestras preguntas a no ser que se «ajusten», comprimiéndolos más o menos, en categorías", por descontado siempre sin descuidar que estas "categorías [...] los respeten lo máximo posible al tiempo que nos permitan llegar a conclusiones"128. Asimismo, una población o un conjunto, según se trate de personas o de datos, "forma[n] una categoría cuando sus miembros [o elementos] comparten una característica que los distingue de los demás", constituyendo "una red cuando sus miembros [o elementos] están relacionados por el mismo vínculo social" o significativo y, por "último, una población [o conjunto] compone[n] una catnet [o telaraña] (categoría + red) cuando se cumplen ambas condiciones: características comunes y vínculos de unión"129.

La cuarta cuestión abunda asimismo sobre las categorías, puesto que un error hermenéutico bastante extendido pretende invalidar todas las especies absolutas. Desde los intentos de Foucault ${ }^{130}$, tal yerro viene a decir que

es obvio que no podemos considerar esos «objetos intelectuales» como «objetos naturales» de los que sólo cambiarían las modalidades históricas de existencia. La locura, la medicina, el Estado no son categorías pensables en el modo de lo universal y de las que cada época particularizaría el contenido. Detrás de la permanencia engañosa de un vocabu-

126. WOOTTON, Barbara: Social Science and Social Pathology. Londres, Allen \& Unwin, 1959 , p. 311.

127. CLARKE, David L.: Analytical Archeology. Londres, Methuen, 1968, p. 37.

128. BURKE, Peter: Sociología..., op. cit., pp. 47s.

129. TILLY, Charles: Grandes estructuras..., op. cit., p. 46.

130. Los primeros trabajos "anti-Absoluto" de Michel Foucault son: La Réponse au Cercle d'Epistémologie (1960), L’Archéologie du Savoir (1969) y L'Ordre du discours (1970). 
lario que es el nuestro, debemos reconocer no los objetos sino las objetivaciones que construyen cada vez una figura original."131

Empleando una expresión de Veyne ${ }^{132}$, pero justo al contrario de como él lo hace, descubrimos la falacia de la argumentación anterior, ya que en este mundo jugamos al ajedrez con figuras eternas: el rey, el alfil, el peón, y son las jugadas, las trampas y las partidas aquello que tras las sucesivas configuraciones sobre el tablero resultan la historia. Otro asunto es que haya una fecha, y un desarrollo acotado, de los particularismos nacidos de las categorías universales; verbigracia, la "locura" es una enfermedad del hombre definible como "la enfermedad mental"133, universal y por ello permanente categorización que no niega, empero, la interpretación dada a la misma y sus divisiones y parientes ${ }^{134}$ a lo largo de las épocas y grupos humanos. Es decir, no cabe confundir construcción de un sentido con el auténtico sentido sobre el que se opera el constructo; ejemplos haylos a miles: que el Sol fuese considerado en algunos cronotopos como una deidad, por mentar un ejemplar clásico, no hace que nuestro astro deje en ningún momento de ser una estrella. Distinto caso es el de las pseudocategorías, como la de "Estado", pues el mismo sí es una objetivación de una categoría: la de "Gobierno"; en esta última, efectivamente, vemos expresada su condición universal, requisito ineludible para poder detectarla como categoría, dado que gobierno de unos hombres sobre otros lo ha habido siempre con independencia de su calidad y cantidad. Como nos recuerda Croce ${ }^{135}$ :

Las categorías no cambian, ni siquiera con el cambio que se llama enriquecimiento, porque ellas mismas son las que operan el cambio, pues si el principio de cambio cambiara también, el movimiento se detendría. Lo que cambia y se enriquece no son las categorías, sino nuestro concepto de las categorías que va recogiendo en sí todas las nuevas experiencias mentales, de modo que nuestro concepto, por ejemplo, del acto lógico, ha ganado ya en malicia y defensa más de lo que tenía el de Sócrates y Aristóteles, y, sin embargo, tales conceptos, más pobres o más ricos, no serían conceptos del acto lógico si la categoría de «logicidad» no permaneciera constante e identificable en todos ellos.

131. CHARTIER, Roger: El mundo como representación. Estudios sobre historia cultural. Barcelona, Gedisa, 2005, p. 42.

132. VEYNE, Paul: Comment on Ecrit l'Histoire Suivi de Foucault Révolutionne l'Histoire. París, Seuil, 1978, p. 236.

133. OCHOA, Elena F. L. (coord.): “Presentación”, en KASSEM, Santiago, OSÁCAR, Arturo y UNCAL, José M.: La locura. Madrid, Santillana, 1996, pp. 8-9 (cita en p. 8).

134. Así: "psicosis agudas, depresiones endógenas, paranoias y «neurosis»" (OCHOA, Elena F. L.: Presentación..., op. cit., p. 9). El entrecomillado es nuestro, a fin de resaltar un trastorno "pariente" de la locura, pero que no es la tal en puridad.

135. CROCE, Benedetto: La historia como hazaña de la libertad. México, FCE, 2005, pp. 34s. 
La quinta cuestión es la relativa al ya mentado juego de escalas ${ }^{136}$, donde lo mismo que debe haber un "proceso de trabajo hacia dentro, de lo general a lo particular", también interesa la inquisición inversa, o sea, el que "trabaja hacia fuera, de lo particular a lo general, describiendo el proceso de cambio de una sociedad que [así puede] contribuir a la construcción de un modelo general revisado"137. Auscultar en ambas direcciones con ida y vuelta, o de lo "macro" a lo "micro"138 y viceversa139, como ya decíamos hacia el final del 2o epígrafe y en la nota 41, es lo que Platón Ilamaba la symploké en su diálogo del "Sofista"140; lo mismo para examinar "la movilidad social" que "el cambio social", o en verdad cualesquiera otras cuestiones, cabe un escrutinio desde la generalidad y uno desde la particularidad a la par, pues ante todo son tan complementarios como necesarios. Así pues, la symploké o entrelazamiento, cuyo correlato en las ciencias naturales es el fenómeno cuántico homónimo ${ }^{141}$, atiende a la relación de los componentes de un sistema o de varios sistemas, inclusive de todos los habidos como en el caso de la holarquía que es el mundo histórico; importan, por tanto, lo mismo las conexiones y continuidades como las desconexiones y discontinuidades (siempre parciales) mutuas entre elementos, series, procesos, dinamismos, etcétera, contenidos en una symploké dada, la cual de este modo sirve igualmente para estudiar situaciones mudables como estables, independientemente de los plazos temporales de ambas. Y es que el juego de escalas incumbe igualmente al decisivo factor tiempo, lo mismo si hablamos de los cronotipos sociales ${ }^{142}$ como

136. Véase la nota 21 y su parágrafo remitente.

137. BURKE, Peter: Sociología..., op. cit., p. 101.

138. Es decir, que "las generalizaciones a largo plazo sobre los fenómenos históricos [son,] de hecho, no sólo posibles sino deseables", puesto que resultan del "esfuerzo por combinar de manera coherente las preocupaciones respecto a la unidad de análisis, la preocupación por las temporalidades sociales y la preocupación por las barreras que se [han] erigido entre las diferentes ciencias sociales", dado que el "estar en contra del particularismo disfrazado de universalismo no significa que todos los puntos de vista son igualmente válidos y que la búsqueda de un universalismo pluralista es fútil" (WALLERSTEIN, Immanuel: Análisis de sistemasmundo. Una introducción. México, Siglo XXI, 2005, pp. 30, 32 y 38).

139. Esto es, investigar "partiendo de episodios aparentemente menores con el fin de trascender el caso [, ya que, en] una narración histórica, el hecho concreto puede tomarse como la respuesta local a una pregunta universal y con ello podemos ahondar en el conocimiento humano" (PONS, Anaclet y SERNA, Justo: La historia cultural. Autores, obras, lugares. Madrid, Akal, 2005, p. 27).

140. PLATÓN: Diálogos (vol. V) Parménides, Teeto, Sofista, Político. Madrid, Gredos, 1988, pp. 428-435.

141. ACZEL, Amir D.: Entrelazamiento. El mayor misterio de la física. Barcelona, Crítica, 2008.

142. GURVITCH, Georges: La vocation actuelle de la Sociologie. París, PUF, 1969, pp. 388ss, habla de "los varios tiempos sociales": Tiempo de larga duración ralentizado (la longue durée, préstamo de Braudel), Tiempo engañoso (el coyuntural o de duración media, también braudeliano), Tiempo pulsátil irregular (el de los transitores o periodos de cambio edadil entre dos Edades), 
si lo hacemos de los historiográficos (Edades, Épocas, Eras, Evos...), pues varios son los grados, ritmos, calidades y demás de las cronologías y temporalidades de la cliosfera. Tanta es la importancia del tiempo en la cliología que es el núcleo de sus estudios, ya que los hombres y los hechos del pasado, por más que estén contextualizados or analizados relacionalmente, pueden comprenderse igualmente en el trabajo de un psicólogo, un sociólogo, un filósofo, un mediólogo, un antropólogo o un etnólogo, por no decir un médico, un político, un físico, un economista o un jurista -por ejemplo- si su especificidad lo facilita; tampoco importa sólo el hombre o el hecho si les añadimos un rastreo genético, ya que los antecedentes pueden en ocasiones interesar a sus puntuales esclarecimientos, y lo pueden realizar cualesquiera de los científicos mencionados en aras de una mejor comprensión or explicación; asimismo, ni siquiera el seguimiento exhaustivo de los susodichos hombres y sus hechos elude todavía el competente tratamiento multidisciplinar; con este panorama parecería, visto lo visto, que la dimensión temporal no es exclusiva de la cliología, ya que las catas del pasado y del presente pueden ( $y$ a menudo lo hacen) manejarse con toda propiedad en otras ciencias. Mas el lector avisado ya habrá advertido el hueco temporal diferido hasta ahora: el futuro. Efectivamente, la dimensión temporal a la hora de abordar un objeto (esto es, los hombres y sus hechos que mencionábamos) es la que define -al diferenciarla- a la cliología respecto de las demás ciencias; y un laboreo tempóreo incluye pasado, presente y futuro, lo cual conlleva que el estudio historiográfico se ocupa de los orígenes abocados en un presente más las repercusiones de ambos en el futuro del historiador o en alguno de los futuros intermedios hasta él, prognosis aparte.

La sexta cuestión es la atinente a la comprensión/explicación, que hoy ha derivado hasta establecer una nueva dicotomía: la explicación/narración ${ }^{143}$; además de su preclara importancia, el hecho de que a partir de su crítica se pretenda defenestrar la cliología justifica nuestra detenida reflexión. En la recrea-

Tiempo cíclico (el de las comunidades arcaicas), Tiempo retrasado de sí o retrógrado (v. gr., el tiempo feudal), Tiempo alternante retroavanzador (el de la competencia entre el pasado y el futuro), Tiempo adelantado de sí (v. gr., el tiempo actual) y Tiempo explosivo (el de las revoluciones y las guerras), a los cuales cabe sumar el Tiempo succionado o vacío (v. gr., el de la contemplación de la televisión, descrito por BOURDIEU, Pierre: Sobre la televisión. Barcelona, Anagrama, 1997, p. 27; o el no menos "aplanado" del progreso dogmático, criticado en su tesis XIII por BENJAMIN, Walter: La dialéctica..., op. cit., p. 60), el Tiempo perdido (v. gr., el del olvido), el Tiempo vencido (el de la cliología y el de la memoria), el Tiempo muerto o kairós (que es el final oportuno de los tiempos), y el Tiempo mesiánico (siempre redentor y siempre posible, como lo recoge, en su tesis XIX, BENJAMIN, Walter: La dialéctica..., op. cit., pp. 64s), el cual figura la eternidad.

143. MARRAMAO, Giacomo: "Neu-Zeit. Modernidad y experiencia del tiempo", en Anthropos, Barcelona, no 223, 2009, pp. 119-133 (especialmente pp. 124-127). 
ción del pasado dos son los presupuestos fundamentales: el testigo (o indicio testimonial) y el observador de segundo orden ${ }^{144}$ (o historiador); ambos comparten el acto de observar, mas la del cliológo es una observación sobre observaciones del pasado ${ }^{145}$. Al fondo, este dueto clásico que acabamos de mentar reproduce "la famosa dupla res gestae/rerum gestorum", la cual adviene como "un desglose conceptual [...] que es el punto de partida para toda reflexión histórica"146; así pues, en primer término la historia acontecida o Geschichte como comprensión (el testigo) y aprehensión (el indicio), y en segunda instancia la historia narrada (la historiografía) tras su investigación cognitiva o Historie (la cliología). Henos aquí la ineludible conjunción, muy bien condensada por Droysen en su máxima de "comprender investigando"147. El correlato con la no menos clásica división "entre la actividad de observar con el propósito de actuar y la actividad de observar con el propósito de comunicar, de hacer inteligibles la sociedad o la historia a tal o cual audiencia"148, da pie al autor citado ${ }^{149}$ a negar que quienes actúan (comprenden) puedan explicar y, en contrapartida, quienes comunican (y por tanto tratan de explicar) están imposibilitados para comprender; estos últimos, que serían los historiadores en nuestro caso, se sobrentiende que no podemos actuar en el pasado que explicamos cuando éste está radicalmente alejado de la propia cronología vital, mas de no ser así, verbigracia en el estudio de la actualidad, pasaríamos a engrosar la primera categoría. Ergo, merced este último ensalmo, tampoco podríamos explicar nada digno de dicho verbo, por mucha profesionalidad que pudiésemos ostentar, y ello simplemente por el atrevimiento de cambiarnos de bando. La majadería es de calado, pues en último término lo que nos iguala a ambos observadores es la imbecilidad, bien que manifiesta en dos modalidades a cuál peor. Finalmente, es cuanto menos curioso que se pueda defender la teoría de la evolución biológica, donde unas especies desembocan en otras, por más que

144. LUHMANN, Niklas: Complejidad y modernidad: De la unidad a la diferencia. Madrid, Trotta, 1998, p. 33.

145. MENDIOLA, Alfonso: "El giro historiográfico: la observación de observaciones del pasado", en MORALES, Luis G. (comp.): Historia de la historiografía contemporánea (de 1968 a nuestros días). México, Instituto IDJMLM, 2005, pp. 509-537.

146. PALTI, Elías J.: "Pensar históricamente en una era postsecular. O el fin de los historiadores después del fin de la historia", en IZQUIERDO, Jesús y SÁNCHEZ, Pablo (eds.): El fin de los historiadores..., op. cit., pp. 27-40 (cita en p. 28).

147. DROYSEN, Johann G.: Histórica. Lecciones sobre..., op. cit., p. 35.

148. MOSCOSO, Leopoldo: "¿En qué consiste pensar históricamente?, en IZQUIERDO, Jesús y SÁNCHEZ, Pablo (eds.): El fin de los historiadores..., op. cit., pp. 3-26 (cita en p. 15).

149. En las "distinciones" que explaya (pp. 15-22) dice Leopoldo Moscoso seguir a PIZZORNO, Alessandro: "Spiegazione come Reidentificazione", en RICOLFI, Luca y SCIOLLA, Loredana (eds.): Il Soggetto dell'Azione (Paradigmi Sociologici ed Immagini dell'Attore Sociale). Milán, Franco Angeli, 1989, pp. 187-210, donde las ideas expuestas son muy interesantes, más no así las peyorativas consecuencias pontificadas que rayan en lo ridículo. 
falten fósiles en el registro de tales cadenas filogenéticas ${ }^{150}$, negando en el ínterin la posibilidad de conocer sobre nuestros propios ancestros pese a contar con pruebas "fosilizadas" de toda laya y perfectamente secuenciadas... ¡si incluso tenemos pruebas pensantes, parlantes y escribanas desde antes de los logógrafos! En definitiva:

La historia, cuando es «científica» y no se reduce a una mera crónica o relato, es una investigación de la lógica de acontecimientos en una parte del pasado con actores e instituciones relevantes [; así,] estudia la interrelación existente entre el cambio histórico y los determinantes de la acción humana. [Dichos] determinantes enraízan hasta un punto considerable, por no decir decisivo, en la estructura de la trama social: en la distribución de roles y en la institucionalización de pautas de conducta. [...] De modo que las acciones de los hombres vienen determinadas por su situación histórica, pero la situación histórica es ella misma resultado de las acciones de los hombres"151.

La séptima y última cuestión es, como no, la del método. Dicha metodología es más que abundante: desde las revelaciones y figuraciones más antiguas, no siempre tan estrictamente míticas como vienen denunciadas, hasta los reportajes testimoniales o casi atestados, y desde las crónicas mayormente teológicas a las románticas repoetizaciones efusivas de un Michelet, seguidas de los rigores crítico-filológicos de un Ranke hasta los actuales y muy numerosos compendios presentes en varios paradigmas metódicos. De cualquier modo, los caracteres universales del método histórico son el conocimiento testimonial, su crítica y la secuenciación temporal ${ }^{152}$, sin que ello menoscabe la multitud de métodos monográficos habientes. Tales metódicas advienen manejadas en razón

150. Como señala SMITH, Wolfgang: La evolución: hechos y fantasías. Palma, José J. de Olañeta, 2010, p. 14, "más abundantes que los fósiles precámbricos son las teorías que se han propuesto para explicar su ausencia. [...] La dificultad básica -es decir, la ausencia de formas intermedias- persiste [asimismo] en todos los estratos cámbricos y posteriores, ricos en fósiles, como se ha señalado repetidamente, empezando por Darwin. El hecho es que «la mayoría de los tipos fundamentales del reino animal se nos presentan sin antecedentes desde el punto de vista paleontológico", como observó Depéret en 1907"; y así prosigue hasta hoy, mal que les pese a tantos seguidores de la "doctrina transformista" -como la bautiza el mismo Smith (p. 24)-, quienes han logrado el amparo científico de "concordar con la Weltanschauung dominante" (p. 21).

151. WRIGHT, Georg H. von: "El determinismo y el estudio del hombre", en MANNINEN, Juha y TOUMELA, Raimo (comps.): Ensayos sobre explicación y comprensión. Contribuciones a la filosofía de las ciencias humanas y sociales. Madrid, Alianza, 1980, pp.183-204 (cita en p. 203).

152. Las secuencias y sucesiones históricas son elementos centrales en las teorizaciones de GORDON CHILDE, Vere: Teoría de la historia. Buenos Aires, La Pléyade, 1976, y XÉNOPOL, Alexandru D.: Teoría de la historia. Madrid, Daniel Jorro, 1911. 
de las necesidades problemáticas de lo historiado, y se nutren no obstante, en todo caso, con las generalidades antedichas; por nombrar algunos de estos métodos sectoriales: espigamos a los totalizadores ${ }^{153}$, indiciarios ${ }^{154}$, conceptual-históricos ${ }^{155}$, cliosemánticos contextuales ${ }^{156}$, arqueológicos ${ }^{157}$, semióticos ${ }^{158}$, histórico-culturales (con el citado Roger Chartier a la cabeza), cliométricos o el revitalizado narrativo por no alargar la lista en exceso. Estrictamente, dichos métodos van desde el inferencial predicado por Collingwood como más propio de la cliología159 a los mentados develador, figurativo, reportero, filológico, crítico, geográfico, genealógico, descriptivo, genético, inductivo y un largo etcétera ${ }^{160}$. Por otro lado, todos los métodos comparten las cuestiones antecedentes reseñadas supra, más la necesidad de problematizar161 lo estudiado, teniendo asimismo presente en todo momento el "caché", el "pilón", los "entornos", las "cuerdas", los "territorios", la "narratio" y la "síntesis".

El pilón es la encuesta matriz de la cliología, conformado con las periodísticas "seis uves dobles inglesas" del lead: qué, quién, dónde, porqué, cuándo y cómo, más las cliológicas "cuánto" y "cuál"; su bautismo proviene de la clásica fórmula metafórica: "beber del pilón", es decir, el estar bien informado por recurrir a las fuentes primarias del conocimiento que busquemos. Los entornos son los "espacios" en que se desarrolla el vivir humano, comenzando por el Natural y siguiendo con el Habitante y el Telemático ${ }^{162}$ (que comprende los locus artefactual ${ }^{163}$,

153. BRAUDEL, Fernand: El Mediterráneo y el mundo mediterráneo en la época de Felipe II. México, FCE, 1976.

154. GINZBURG, Carlo: Mitos, emblemas, indicios. Morfología e historia. Barcelona, Gedisa, 1989, pp. 138-175.

155. KOSELLECK, Reinhart: Los estratos del tiempo: estudios sobre la historia. Barcelona, Paidós, 2001.

156. BUSSE, Dietrich: Historische semantik. Stuttgart, Klett-Cotta, 1987, POCOCK, John G. A.: The Machiavelian Moment. Florentine Political Thought and the Atlantic Tradition. New Jersey, PUP, 1975 y SKINNER, Quentin: Visions of Politics (3 vols.). Cambridge, CUP, 2002, entre otros.

157. CLARKE, David L.: Analytical..., op. cit., y FOUCAULT, Michel: La arqueología del saber. México, Siglo XXI, 2003, por citar algunos.

158. LOTMAN, luri M. y Escuela de Tartu: Semiótica de la cultura. Madrid, Cátedra, 1979.

159. COLLINGWOOD, Robin G.: Idea de la historia. México, FCE, 1986, pp. 241-249.

160. Una lista metodológica bastante completa es la confeccionada por TOPOLSKI, Jerzy: Metodología de la Historia. Madrid, Cátedra, 1992, pp. 175-515.

161. MONIOT, Henri: "La historia de los pueblos sin historia", en GOFF, Jacques le y NORA, Pierre (dirs.): Hacer la historia (vol. I), op. cit., pp. 117-134, destaca que los "medios de una investigación histórica son los materiales documentales, y la actividad intelectual (problemática, crítica...) que los busca, los reconoce, los explota, los hace útiles... por lo demás, ambos imbricados de forma indisoluble y continua" (p. 120).

162. ECHEVERRÍA, Javier: Los Señores del Aire: Telépolis y el Tercer Entorno. Barcelona, Destino, 1999.

163. DERRIDA, Jacques y STIEGLER, Bernard: Ecografías de la televisión. Entrevistas filmadas. Buenos Aires, Eudeba, 1998, p. 15. 
simbólico ${ }^{164}$ y cliosférico). Después, las mentadas cuerdas, donde los territorios son a su vez subdivisiones de ellas, para los cuales tenemos, por ejemplo, una propuesta para el medievo: "demografía-sociedad-economía; estado-instituciones-guerra; religión-Iglesia; filosofía-ciencias-enseñanza; literaturas; arqueología-arte; y mentalidades-comportamientos"165. La ya mentada narratio es la insuperable horma de comunicar, formular y pensar la historia, puesto que asume el mejor reflejo del equilibrio dinámico ${ }^{166}$ propio de todo lo humano; como dice Veyne, las explicaciones del historiador consisten en mostrar el desarrollo de la trama de la historia que acotemos, alcanzando finalmente, así, una tarea de comprensión más que de explicación ${ }^{167}$, empatía con el mundo pasado adquirida siempre que con los hechos busquemos "las narraciones significativas"168 de los mismos. En definitiva, para nosotros, la explicación adviene como la comunicación a los demás de lo que vamos comprendiendo. Y por fin la síntesis, con tanto ahínco y justicia reclamada en la obra de Berr"169, que es el corolario capital de todo trabajo histórico; de "acuerdo con este principio, la labor del historiador [debe] ceñirse a un doble proceso: análisis detallado de los documentos y posterior síntesis"170. Así, no se trata de registrar la "vida humana" las 24 horas del día de los 365 días de cada año, al modo de las cámaras de seguridad de muchos negocios, sino de tener presente que la cliología es

la ciencia que trata de describir, explicar y comprender los fenómenos de la vida, en cuanto se trata de los cambios que lleva consigo la situación de los hombres en los distintos conjuntos sociales, seleccionando aquellos fenómenos desde el punto de vista de sus efectos sobre las épocas sucesivas o de la consideración de propiedades típicas, y dirigiendo su atención principal sobre los cambios que no se repiten en el espacio y en el tiempo."171

164. ELIAS, Norbert: Sobre el tiempo. México, FCE, 1989, p. 45.

165. GLENISSON, Jean: "Tendances, methodes et techniques nouvelles de I'histoire medievale", en Tendances, perspectives et methodes de l'Histoire Medievale (Actes du 100 Congrés National des Societés Savantes). París, 1977, pp. 8-21. Con los territorios, todavía estamos manejando unidades de análisis mayores (es decir, generales), que por descontado se subdividen en muchos otros elementos menores (es decir, específicos), como los "campos", descritos por BOURDIEU, Pierre: El sentido práctico. Madrid, Taurus, 1991; en estas y otras divisiones, la peculiaridad cognitiva radica en que no van a figurar en los trabajos historiadores que no lo demanden especialmente.

166. PARETO, Wilfredo: Traité de sociologie générale. París-Génova, Librairie Droz, 1917, capítulo XII.

167. VEYNE, Paul: Cómo se escribe la historia. Ensayo de Epistemología. Madrid, Fragua, 1972, p. 118.

168. DANTO, Arthur: Historia..., op. cit., p. 61.

169. BERR, Henri: La síntesis en Historia. Su relación con la síntesis general. México, UTEHA, 1961.

170. MITRE, Emilio: Historia y pensamiento histórico. Estudio y antología. Madrid, Cátedra, 1997, p. 60.

171. BAUER, Wilhelm: Introducción al estudio de la historia. Barcelona, Bosch, 1970, p. 38. 
O como recuerda Pomian:

practicar la historia no es sólo establecer los hechos. También es hacerlos inteligibles, integrándolos en esquemas de los que se admite que son capaces de conferirles un sentido. [Vemos, pues], que la historia no está condenada a elegir entre los hechos insignificantes y las significaciones arbitrarias, sino que puede realizar síntesis monográficas que tengan un fundamento teórico, adaptando a su uso los cuestionarios de la economía, de la sociología, de la antropología, de la demografía, etc."172

\section{Vamos a estudiar la cliosfera: la teoría del paralipómeno o sistema-mundo- histórico}

Yendo ya sobre la teoría, pasamos a conjuntar lo recogido hasta aquí. Cabe advertir, en primer lugar, que el tratar sobre la categoría de naturaleza humana (el individuo) y también sobre la categoría de interacción humana en una estructuración social (la sociedad), no significa que les confiramos "naturaleza representacional"; dicha "concepción [ha de tener] su origen en la mera observación de la realidad humana"173 para que su lugartenencia o representancia ${ }^{174}$ histórica resulte asimismo transhistórica desde su ahistoricidad. Por ello, nuestro marco teórico no se modula desde unas determinadas concepciones sincrónicas y tópicas, antes bien, se introduce en la especificidad del cronotopo estudiado; con ser suficientemente general, nuestra teoría la podemos considerar como un conocimiento especulativo con independencia de toda aplicación. Así, será partiendo de su aplicación en cada caso de donde dimanarán los significados pertinentes, y no al revés (el efecto corsé) como suele ser lo habitual, esto es: tratamos "de crear modelos de progresión para conceptos abarcativos más amplios $^{\prime 175}$. Conforme apunta Taylor, se trata de encontrar el punto arquimédico en el cual, por un lado, la investigación recree los significados atribuidos por los hombres del pasado a sus aconteceres, explicados además tales procesos mediante su conceptualización teórica, y, en el otro polo, plasmar dicha indagación desde nuestra propia conceptuación actual ${ }^{176}$. Definida toda teoría como una "hipótesis cuyas consecuencias se aplican a toda una ciencia o a parte muy im-

172. POMIAN, Krzysztof: Sobre la..., op. cit., p. 81.

173. CABRERA, Miguel A.: "La historia y los historiadores tras la crisis de la modernidad", en IZQUIERDO, Jesús y SÁNCHEZ, Pablo (eds.): El fin de los historiadores..., op. cit., pp. 4160 (cita en p. 44).

174. RICOEUR, Paul: La historia, la memoria, el olvido. Madrid, Trotta, 2003, pp. 311-376.

175. ASHBY, Rosalyn, DICKINSON, Alaric y LEE, Peter: Las ideas de los niños..., op. cit., p. 219.

176. TAYLOR, Charles: La libertad de los modernos. Buenos Aires-Madrid, Amorrortu, 2005, pp. 199-222. 
portante de la misma [, en] un intento de interpretación explicativa mediante la generalización de hechos comúnmente admitidos sin discusión [; y, también, como una serie] de leyes que sirven para relacionar determinado orden de fenómenos"177, nos resta añadir alguna precisión. Así, convenimos con Tilly ${ }^{178}$ que lo primordial es que la teoría nos proporcione un modelo válido para entender el mundo, un mapa conceptual "que represente la realidad y la simplifique de la forma que mejor se ajuste a nuestros propósitos"179; así, Ilamamos "teorías a aquellos conjuntos de proposiciones, referidas a la realidad empírica, que intentan dar cuenta del comportamiento global de una entidad, explicar un fenómeno o grupos de ellos entrelazados [, y además, dicho] conjunto [...] debe tener una explícita consistencia interna y estar formulada alguna de [sus proposiciones] en forma de «ley»"180.

$\mathrm{Al}$ igual que todo conjunto, el del paralipómeno es pertinente dividirlo en sus múltiples constituyentes, donde los "lazos necesarios entre elementos constitutivos que dan a un sistema su identidad invariante los Ilamaré su organización [, y] a lo que cambia sin dejar de permanecer sometido a la organización, lo llamaré estructura del sistema"181; además, cabe aplicar la premisa histórica en este caso mundosistémico, yendo por delante "que lo humano no está [completamente] dado «naturalmente» sino que se constituye en un proceso de aprendizaje, donde el rol de la naturaleza es brindar directrices"182. He aquí la útil plasticidad del paralipómeno, dada la capacidad de sus categorías para encarnarse en prácticas, relaciones, comprensiones y explicaciones; de este modo, la investigación cliológica pretende saber y comprender lo sustantivo que fue fenomenal, cognición llevada a la par con lo que va siendo y con lo que podría ser, explicitando dicha gnosis en una síntesis narrativa sobre el pasado como metáfora intelectiva ${ }^{183}$ del mismo, a fuer de

177. VV. AA.: Enciclopedia Espasa (vol. X) Tareche-Zyrianos. Madrid, Espasa Calpe, 2003, p. 3100.

178. TILLY, Charles: Grandes estructuras..., op. cit., p. 103.

179. HUNTINGTON, Samuel P.: El choque de civilizaciones y la reconfiguración del orden mundial. Barcelona, Paidós. 1997, p. 32.

180. ARÓSTEGUI, Julio: La investigación histórica: teoría y método. Barcelona, Crítica, 1995, p. 42.

181. VARELA, Francisco: "La individualidad: la autonomía del ser vivo", en VV. AA.: Sobre el individuo. Contribuciones al Coloquio de Royaumont. Barcelona, Paidós, 1990, p. 112.

182. CARRETERO, Mario y KRIGER, Miriam: “¿Forjar patriotas o educar cosmopolitas? El pasado y el presente de la historia escolar en un mundo global", en CARRETERO, Mario y VOSS, James F.: Aprender y pensar..., op. cit., pp. 71-98 (cita en pp. 75s).

183. El crucial papel epistemológico de la metáfora viene condensado por TOPOLSKI, Jerzy: "La estructura de las narrativas históricas y la enseñanza de la historia", en CARRETERO, Mario y VOSS, James F.: Aprender y pensar..., op. cit., pp. 101-119 (cita en p. 113), al entender "que los marcos metafóricos ayudan a transmitir los contenidos informativos del texto. De acuerdo con el sentido de las metáforas y de las expresiones metafóricas, muestran las cosas menos conocidas (o menos comprensibles) en términos de los contenidos más comprensibles". 
temporalizada imaginación ${ }^{184}$ recreadora. Por tanto, "el trabajo del historiador [debe] ser [tan] productivo -generar relatos- [como] especulativo - [...] pensar en cómo [han de] ser esos relatos-" 185 , ya que en tales relatos se emplean variedad de recursos literarios (la consabida narratio, donde por descontado tenemos retórica que es "pura ficción"186), así como en no pocas ocasiones enfoques "personalizados" según el estudio de caso ${ }^{187}$ abordado, hasta el punto de la posible ausencia de canon; este último aserto puede parecer contradictorio, mas no es así, ya que lo propuesto en el paralipómeno -que supra ya adelantábamos en parte- es un marco lo suficientemente amplio como para abarcar quequier paradigma al tratarse de un modelo que examina y guía, tanto doxográfica ${ }^{188}$ como peculiarmente a la par que atiende lo macro y lo micro, más lo permanente con lo cambiante y lo colectivo ${ }^{189}$ con lo singular ${ }^{190}$, pues "la historia no consiste [solamente] en una serie de relatos [entramados], sino que es un proceso causal"191. En suma, para nuestro quehacer aplicamos la analítica que bien podemos denominar "clioanálisis".

La organización del paralipómeno descansa en los basamentos, siempre activados por el motor de la historia que es lo que entendemos como más supremo

184. Imaginación que es de suma importancia, como recalca ARENDT, Hannah: De la historia a la acción. Barcelona, Paidós-ICE UAB, 1995, pp. 45s, y también indagada la susodicha importancia por JITRIK, Noé: Historia e imaginación..., op. cit.

185. GONZÁLEZ, Marisa: ¿El fin de los historiadores o el fin de una hegemonía?, en IZQUIERDO, Jesús y SÁNCHEZ, Pablo (eds.): El fin de los historiadores..., op. cit., pp. 153-178 (cita en p. 172).

186. CERTEAU, Michel de: Historia y psicoanálisis. Entre ciencia y ficción, México, UIAITESO, 2007.

187. Aunque el concepto "estudio de caso" se reserva para los trabajos más específicos, nosotros lo empleamos en el sentido amplio de que cualquier historiación, por muy metarrelato que sea, siempre tiene un punto final; con lo cual, siempre se cierra el "caso" historiado, que puede por tanto ser más o menos extenso, empero y sin remisión, con sus inevitables límites.

188. RORTY, Richard: "La historiografía de la filosofía: cuatro géneros", en RORTY, Richard, SCHNEEWIND, Jerome B. y SKINNER, Quentin (comps.): La filosofía en la historia. Ensayos de historiografía de la filosofía. Barcelona, Paidós, 1990, pp. 69-98 (cita en p. 83), define este "género intelectivo" como aquel que recorre "lo que diversas figuras tradicionalmente Ilamadas «filósofos» dijeron acerca de problemas tradicionalmente llamados "filosóficos»" (esto mismo vale para la historiografía: simplemente sustituimos "filósofos" por "historiadores" y "problemas filosóficos" por "problemas cliológicos").

189. "Explicación estructural" es la caracterización de CARRETERO, Mario et al: Construir y enseñar las ciencias sociales y la historia. Buenos Aires, Aique, 1995, p. 371, como definición de "un conjunto de factores económicos, políticos, científicos y sociales como los principales elementos causales de la realidad social en relación con [un] acontecimiento" dado.

190. O "modo narrativo", el cual trata sobre las "vicisitudes de las intenciones humanas" en "las especificidades de la experiencia y" las "consecuencias que caracterizan su curso", al decir de BRUNER, Jerome: Actual minds, possible worlds. Cambridge, Harvard University, 1986, pp. 16 y 13.

191. TOPOLSKI, Jerzy: La estructura de las narrativas..., op. cit., p. 103. 
e ilimitado: el Amor; huelga decir que las pasiones mueven el mundo: por amor al dinero se movilizan guerras, estrategias económicas, rechazos a ideas (esto sería odio, que es la forma negativa del amor), pactos y alianzas, egoísmos de todo tipo, etcétera. En esta primera instancia ya advertimos una característica primordial, cual es la de la jerarquía en la cliosfera ${ }^{192}$; dicha relación jerárquica, empero, no mengua la autonomía de los componentes, es más, ni siquiera impide cierta anarquía en su interrelación, ya que en la escala holárquica los grados no son tanto de importancia y subordinación como de pertenencia y función, es decir: de englobamiento. Los citados basamentos nacen de la triple dimensionalidad ontológica humana: biológica, social y trascendente. La primera fue primada por Weber, con su perspectiva remarcadora de "lo social constituyente"193 o individualista ${ }^{194}$; la segunda sedujo grandemente a Durkheim, quien aportó la perspectiva de "lo social constituido"195 o societal196; y la tercera abarca todo cuanto nos sobrepasa, pues se trata de "lo social constitutivo" o trascendental197; toda esta interactividad se entiende tratada discursivamente, alternativa que logra así "superar la secular disyuntiva entre objetivismo y subjetivismo que ha atenazado a los historiadores"198 durante demasiado tiempo. El carro o merkaba impelido por la motricidad histórica es la Identidad" ${ }^{199}$, siendo "la rueda dentada de la «ma-

192. TOPOLSKI, Jerzy: La estructura de las narrativas..., op. cit., p.108, expone una conclusión muy similar al referirse a la narratio, pues "mientras que existe como parte de una narrativa histórica, cada oración enriquece su contenido individual al participar en los contenidos de las totalidades narrativas de distinto grado. Esta participación suele ser no articulada".

193. GONZÁLEZ, José M.: "El individuo y la sociedad", en CRUZ, Manuel (comp.): Tiempo de subjetividad. Barcelona-Buenos Aires, Paidós, 1996, pp. 19-38 (cita en p. 26).

194. WEBER, Max: Economía y sociedad (vol. I). México, FCE, 1964, p. 5.

195. GONZÁLEZ, José M.: El individuo..., loc. cit.

196. DURKHEIM, Émile: Las reglas del método sociológico. Buenos Aires, Schapire, 1972, p. 33.

197. Aquí entrarían además los intentos sintéticos de ambos enfoques, como los de BERGER, Peter L. y LUCKMANN, Thomas: La construcción social de la realidad. Buenos Aires, Amorrortu, 1972, y sobre todo ELIAS, Norbert: El proceso de la civilización. Investigaciones sociogenéticas y psicogenéticas. Madrid, FCE, 1993, quien sentencia "que conceptos como «individuo» $y$ «sociedad» no se remiten a dos objetos con existencia separada, sino a aspectos distintos, pero inseparables de los mismos seres humanos y que ambos aspectos, los seres humanos en general, en situación de normalidad, sólo pueden comprenderse inmersos en un cambio estructural. [Las] relaciones entre estructuras individuales y estructuras sociales comienza a aclararse en la medida en que se investigan ambas como algo mutable, como algo que está en flujo continuo" (pp. 15s).

198. CABRERA, Miguel A.: Historia, lenguaje y teoría de la sociedad. Madrid, Cátedra, 2001, p. 18.

199. Resumida en las recurrentes y famosas "tres grandes preguntas: ¿de dónde venimos?, ¿quiénes somos? y zadónde vamos?", nuestras vidas son un constante identificar e identificarnos, una incansable vinculación identitaria entre el pasado, el presente y el futuro en nuestros "yoes", juntamente con los que vamos considerando y nos consideran como "nosotros, vosotros y ellos". 
quinaria» que mantiene a la historia en movimiento" la "lógica de acontecimientos [o] interacción entre cambios de situación, intencionalidad, aptitud y un trasfondo motivacional y normativo"200, y es su combustible la "natividad"201. Monta -y es montado por- la merkaba el tetrapotens (Cuatro Potencias ${ }^{202}$ ): orden-caos y absoluto-relativo ${ }^{203}$; estos holones parejos interactúan a las freudianas pulsiones que son los ternarios dínamos: pasión/miedo/olvido (los cuales, como todo el resto que vamos a pergeñar devienen en los universales antropológicos: el lenguaje, el mentalismo ${ }^{204}$, la mímica, la parentela, la mítica, la abstracción, el autocontrol, los afectos ${ }^{205}$ ), libertad/necesidad/responsabilidad, experiencia/expectativa206/vivencia, fe/deseo/jugar (aquí se implican las creencias que vamos adquiriendo, lo que se pretende lograr y el juego que ambas instancias presuponen, ya que la ontología humana descansa en el no-ser-allí o Dortnichtsein -representado bíblicamente en la expulsión del Paraíso ${ }^{207}-$ ), cronotopismo/dentro/fuera (en un tiempo y un lugar determinados: lo que se considera propio y ajeno), hybris/justicia/verdad, amigo/enemigo/tensión ${ }^{208}$, vida/muerte/

200. WRIGHT, Georg H. von: El determinismo..., op. cit., p. 201.

201. ARENDT, Hannah: La condición humana. Barcelona, Paidós, 1993, pp. 21 ss, 201s, 214 y 266; y Reinhart Koselleck en GADAMER, Hans G. y KOSELLECK, Reinhart: Historia..., op. cit., pp. 81-83, quien bautiza este concepto como "generatividad". Dentro de este concepto se aúnan tanto la reproducción biológica como la interacción de las generaciones coetáneas, contemporáneas y alienas (ORTEGA Y GASSET, José: El tema de nuestro tiempo. Madrid, Espasa-Calpe, 1980, pp. 11-26 y passim, y del mismo autor: En torno a Galileo. Madrid, Biblioteca Nueva, 2005, pp. 84-117; asimismo, SCHÜTZ, Alfred: El problema..., op. cit., pp. 45-51 y passim).

202. RANKE, Leopold von: Sobre las épocas de la historia moderna. Madrid, Editora Nacional, 1984, p. 82, ya habla de las "potencias (o modos, Potenzen), que abarcan la vida entera de los pueblos".

203. Auténticos ordenadores y en consabida alternancia edadil, el cuaternario potentado es el mayor referente de la generalidad vivida en las distintas Edades, ya que estos dos pares pluripotentes (capacidad de generar distintos tipos conceptuales diferenciados) están en la raíz de toda cosmovisión humana; las tales cosmovisiones, ora priman el orden ora el caos -que es otro tipo de orden, apud Henri Bergson, como decíamos en la n. 63-, y lo mismo hacen con el absolutismo y el relativismo de la realidad vivida.

204. Mayormente conceptuado con el inapropiado término de "teoría de la mente", el mentalismo "es una competencia cuya función es predecir y «explicar» acciones humanas específicas" (BARQUERO, Beatriz, FONTELA, Federico, NÚÑEZ, María y RIVIÈRE, Ángel: "La influencia de los factores intencionales y personales en el recuerdo de los textos históricos: una perspectiva evolutiva", en CARRETERO, Mario y VOSS, James F.: Aprender y pensar..., op. cit., pp. 197-214 -cita en p. 198-).

205. Pequeña cata de la extensa relación elaborada por BROWN, Donald E.: "Apéndice: Lista de universales humanos de Donald E. Brown", en PINKER, Steven: La tabla rasa. La negación moderna de la naturaleza humana, Barcelona, Paidós, 2003, pp. 627-632.

206. KOSELLECK, Reinhart: Futuro pasado..., op. cit., p. 15.

207. Libro del Génesis, capítulo 3.

208. Dialéctica estudiada por SCHMITT, Carl: El concepto de lo político. Madrid, Alianza, 2009, pp. 56-106, de la cual también Koselleck toma buena nota. 
fama (vivir, morir y perdurar), acción/epojé/anonimia (el actuar humano más su reposo y lo desconocido entrambos, "que proporciona la articulación última entre el tiempo privado y el tiempo universal a través del concepto de anónimo" ${ }^{209}$ ), tradición/otredad/símbolo (tradicionalidad y tradición como la temporalidad propia de la experiencia y su contenido cognitivo ${ }^{210}$, entreverado con las aportaciones foráneas además de estar, todo ello, mediado por el mundo simbólico que cada comunidad elabora), arriba/abajo ${ }^{211} /$ nuclear (la dominación y la subordinación junto a la empresa centrípeta ${ }^{212}$ ) y memoria/metahistoria/prognosis (triplete que expone como ninguno el aludido trasunto de la identidad, ya que la memoria se dirige al pasado, la metahistoria lo trata de legitimar significándolo y la prognosis es la prospección-proyección de lo porvenir).

Acto seguido, colegimos las Leyes de la historia o Regularidades Aproximativas Universales ${ }^{213}$ : de Imperialidad (recordemos la "voluntad de poder" nietzcheana, afán de dominio que abarca desde el propio de cada uno a los totalitarismos y los imperios), Intrahistórica (la unamuniana cotidianeidad de las gentes), de Qohélet (en referencia a las repeticiones de la historia recogidas en al aserto del Eclesiastés 1, 9: "Lo que fue, eso será; lo que se hizo, eso se hará. Nada nuevo hay bajo el sol"), Difusionista (la expansión del conocimiento y de los hombres por todo el mundo), del Apocalipsismo (el vuelco de una manera de vivir o paso de una a otra Edad), Revolutiva (pues siempre hay revoluciones, revueltas, guerras, progresos, regresos, luchas), del Péndulo (significada en la inversión de las idiosincrasias de unos tiempos respecto de los siguientes), de las Masas (por

209. MUDROVCIC, María Inés: Historia, narración y memoria. Los debates actuales en filosofía de la historia. Madrid, Akal, 2005, p. 107.

210. RICOEUR, Paul: Tiempo y narración (vol. II) Configuración del tiempo en el relato de ficción y (vol. III) El tiempo narrado. México, Siglo XXI, 2001-2006, pp. 394-419 y 958-989 respectivamente.

211. Reinhart Koselleck hace también aquí referencia -incompleta, como la remitente-al par dentro/fuera, en DUTT, Carsten y KOSELLECK, Reinhart: "Historia(s) e Histórica. Reinhart Koselleck en conversación con Carsten Dutt", en Isegoría, Madrid, no 29, 2003, pp. 211-224 (cita en p. 212).

212. Dicho empeño centripetador está presente lo mismo en los sujetos en apogeo que en los marginales (vid. ALONSO MARTOS, Andrés y VÁZQUEZ, Manuel E. (eds.): Periferias..., op. cit.).

213. Las leyes de la historia pueden conceptuarse al modo de VEYNE, Paul: Cómo se escribe..., op. cit., p. 202, como "regularidades aproximativas", tal las encontradizas de la vida cotidiana, o, más exactamente, cruzando la calificación de RICOEUR, Paul: Tiempo y narración (vol. I)..., op. cit., p. 198, quien habla de "hipótesis aproximativamente universales", con lo cual tenemos Regularidades Aproximativas Universales como sinónimo de Leyes de la Historia. En este sentido, aunque con otros matices, se pronuncia XÉNOPOL, Alexandru D.: Teoría..., op. cit., pp. 451-477 (cita en p. 147), al hacer análogas las leyes naturales con las series históricas, donde "la serie histórica, al unir en el tiempo los hechos individuales, destruye, o por lo menos neutraliza la acción individualizadota de este último". Vid. asimismo a GORDON CHILDE, Vere: Teoría..., op. cit., pp. 12-30. 
las muchedumbres tan fáciles de manipular unas veces y tan difíciles de controlar otras tantas), Tópica (la vivencia consuetudinaria como moldeadora del carácter) y Cosmográfica (por la decisiva influencia del medio ambiente, de la geografía como condicionantes del hacer humano $\left.{ }^{214}\right)$. Todas estas leyes básicas se desarrollan de dos modos fundamentales: 1) En la reglamentación social de cada comunidad dada, y, por ello, así como puede "caracterizarse la ciencia natural como el estudio de los fenómenos «gobernados» por la ley natural" a su vez las "ciencias humanas, por su parte, consisten primordialmente en el estudio de los fenómenos "gobernados» por reglas e instituciones sociales"215; y 2) En las proposiciones derivadas del libre actuar de los hombres (albedrío con sus limitaciones, condicionantes, tabúes y tradiciones imbricadas, como se sobrentiende), relaciones que pueden ser cuantitativas y casi constantes, ordinales de análisis estructural216, de evidencia, de repetición y de evolución ${ }^{217}$, en suma: trabazones dialécticas (o trialécticas, según algunos neologistas de última hora), correlacionales y comprensivas.

Después tenemos los clióforos (portadores de la "musa" Clío): las constantes históricas (que son las tendencias presentes en todo tiempo); las cliosaltaciones (que son aquellas trazas que menguan durante ciertos períodos para sobredimensionarse en otros, como a "saltos"); la triangulación (elemento funcional presente en la mayoría de los componentes del paralipómeno, cuya principal característica es la correlación a tres bandas ${ }^{218}$ ); el contrapuesto (elementos generalmente dicotomizados, pero que en verdad son polarizaciones complementarias); la tymocción (singularidad de la acción humana); los gestemas (caracteres fundamentales en todo tiempo, así llamados cuando alcanzan el primer grado de importancia); la acontecicepción (proceso recepcionista de los acontecimientos, por el cual podemos asimilarlos, trabajarlos o rechazarlos -en lo que constituye toda una gestáltica-); los entornos; las cuerdas; los documentos (toda

214. VILAR, Pierre: "Historia marxista, historia en construcción", en GOFF, Jacques le y NORA, Pierre (dirs): Hacer la historia (vol. I)..., op. cit., pp. 179-219 (cita en pp. 205-207).

215. WRIGHT, George H: El determinismo y el estudio..., op. cit., pp. 183s.

216. PIAGET, Jean: "La situation des sciences de I'home dans le système des sciences", en BIE, Pierre de, BOUDON, Raymond, BOURGEOIS-PICHAT, Jean et al: Tendances principales de la recherche dans les sciences sociales et humaines. París-La Haya, Mouton-UNESCO, 1970, pp. 1-65.

217. BOUVIER-AJAM, Maurice: Essai de Méthodologie Historique. París, Le Pavillon, 1970.

218. DOLTO, Françoise: "La aparición del «yo» gramatical en el niño", en VV.AA., Sobre el individuo..., op. cit., pp. 91-109 (cita en p. 107), quien expone el ejemplo de la relación padres-hijo: "la madre en cosensorialidad con el padre constituyen una triangulación de seguridad. Esta triangulación es lo que el sujeto, con su cuerpo y a través del espacio, persigue continuamente en sus relaciones con otros sujetos que tienen cada uno su cuerpo, su historia inscripta en este cuerpo, y de la que el sujeto, testigo de este cuerpo, ha conservado memoria". 
huella del pasado); el pilón; la narratio (que comprende tanto la escritura de la historia como la investigación, la comprensión y la explicación); la symploké; la síntesis; los galimatías (complejo transversal de unidades de análisis cliológico); la liminalidad (todas las fronteras y limitaciones de la historia); los clioremas (o teoremas cliológicos, esto es: proposiciones estables y necesarias concurrentes en determinadas formulaciones de trasuntos, problemas, objetos... v, gr., desde la poética historiográfica sabemos que siempre cabe indagar en "las condiciones de articulación del triple contrato científico, narrativo y político" 219 así como equilibrar los "aspectos cognitivo, filosófico y literario" 220 para todo estudio histórico); las funciones y funcionamientos (categorías de índole práctica y generalista); los sujetobjetos (naturalizaciones, personalizaciones y reificaciones de sujetos y objetos históricos ${ }^{221}$ ); los universales; los arquetipos; las praxis (o prácticas que determinados grupos sociales emplean en la vida diaria ${ }^{222}$, incluyéndose aquí el triplete relacional categoría-red-telaraña examinado supra); las cliotendencias (tendencias destacadas en un período dado); la perihistoria (todos aquellos pueblos desfasados de la Edad imperante); las escalas (aquí se incluyen, además de la escala propiamente dicha -como instrumento de estudio-, las distintas posibilidades de agrupación, desde el eremita solitario y su correlato que es la biografía a las familias, los clanes, las tribus, las sociedades, las culturas, las civilizaciones y las aglomerizaciones ${ }^{223}$ ); los cliologemas ("frases hechas historiográficas", datadas para sintetizar los más diversos eventos históricos); las fases biohistoriables (divisiones temporales y cualitativas de una civilización, un sujetobjeto, un fetiche); los conectores (aconteceres que sirven de enlace entre diversos estatus); los excedentes (derivaciones, remanentes, desechos y residuos de sentido y de acción en las simbolizaciones y en las factualidades ${ }^{224}$ ) y los cliodeos (formaciones invariantes de variables expresiones ${ }^{225}$ ).

219. RANCIÈRE, Jacques: Los nombres..., op. cit., p. 31.

220. POMIAN, Krzystof: Sobre la..., op. cit., p. 82.

221. PEREYRA, Carlos: El sujeto..., op. cit., pp. 9, 56-78 y passim; así como PIAGET, Jean: La situation des sciences..., op. cit., pp. 18s, quien distingue un doble plano operatorio en el sujeto-objeto humano, encontrándonos de este modo ante un "sujeto egocéntrico" y un "sujeto epistémico".

222. CERTEAU, Michel de: La invención de lo cotidiano (vol. I) Artes de hacer. México, UIAITESO, 2000.

223. Término conceptual de NANCY, Jean L.: La creación del mundo o la mundialización. Barcelona, Paidós, 2003, p. 14, que refiere los grandes bloques conformados por varias civilizaciones, al modo huntingtoniano (aunque este autor las denomina simplemente como civilizaciones, además de no coincidir nosotros exactamente con sus conjuntos); así, nosotros proponemos: Occidente, Islámica, Africáner, Hindi y Sínica. Además, sobre las escalas vid. I, II 2 을

224. Vid. II, II 20, más notas 61 y 62 .

225. Como sentencia DEBRAY, Régis: El arcaísmo posmoderno..., op. cit., p. 41, "Si una estructura formal es una invariante, la administración de la invariante es eminentemente variable". 
La parte estructural del paralipómeno comprende a las personas, personalidades y personajes: actores, actores-agentes, agentes-actores y agencias, y a los gestáforos (portadores de gestas): evos, períodos, transitores, vertebraduras, coyunturas, episodios, acontecimientos y sucesos. Al evo (puente primero entre lo variante y lo invariante, tal muchas costumbres y comportamientos estereotipados, así como las mismas concepciones que vamos teniendo del tiempo) corresponde una temporalidad más larga que la duración braudeliana; el período sería lo que Braudel definió como longue durée 226 (v. gr., el Ancien Régime); el transitor refiere las ocurrencias y el tiempo transitivo entre dos edades; la vertebradura se explaya dentro de cada período en un tiempo medio-largo al tratarse de una generalidad sociopolítica; la coyuntura comprende un tiempo mediocorto, ya que su carácter se limita a menos de lo propio de una Edad; al episodio compete el tiempo breve, pues define una singularidad o evento; el acontecimiento, como parte de un episodio que es, posee un tiempo brevísimo; y el suceso encarna la temporalidad puntual, ya que siempre son varios sucesos los necesarios para conformar un acontecimiento.

Y al fin, la parte histórica del paralipómeno, que congrega en primer lugar a los historíforos (portadores de historia): Edades, épocas, eras, múltiplex (conjunción de la pluralidad temporal, visible en determinados momentos como arcaísmos o adelantamientos dentro de lo general dado -v. gr., la superstición en nuestra era científica-), índoles, cronotopías, cronovisiones (cronometrías, cronografías, cronologías y cronosofías -futuriciones socialmente construidas-227), cronogramas (fases de un cronotopo $^{228}$ ), pragmatae (prácticas constitutivas de un campo social ${ }^{229}$ ), fetiches (animaciones, humanizaciones o divinizaciones realizadas sobre cosas, procesos, fenómenos, etc.), campos (subdivisiones grupales de una sociedad), clioaspectos (tensiones, incongruencias ${ }^{230}$, proteidades, aprioris, impulso,

226. BRAUDEL, Fernand: La historia y las ciencias sociales, Madrid, Alianza, 1968.

227. POMIAN, Krzysztof: El orden del tiempo. Madrid, Júcar, 1990, pp. 13-22 y passim, quien define las cronovisiones como "maneras de visualizar el tiempo, de traducirlo en signos" (p. 17).

228. MENDIETA, Eduardo: "Modernidad, posmodernidad y poscolonialidad: una búsqueda esperanzadora del tiempo", en CASTRO, Santiago e íd. (coords.): Teorías sin disciplina. Latinoamericanismo, poscolonialidad y globalización en debate. México-San Francisco, Miguel Ángel Porrúa-USF, 1998, pp. 147-168 (cita en p. 159).

229. MARRAMAO, Giacomo: Poder y secularización. Barcelona, Península 1989, pp. 100-107 y passim.

230. Entre la cultura y el sistema social se reproduce una competición integradora, y como "los dos tipos de integración no son idénticos y la forma particular de uno de ellos no implica la que tomará el otro, hay entre ambos una incongruencia y una tensión inherentes": VOGT, Evon Z.: "Sobre los conceptos de estructura y proceso en antropología cultural", en SAZBÓN, José (dir.): Estructuralismo e historia. Buenos Aires, Nueva Visión, 1972, pp. 67-90 (cita en p. 79). 
madurez, saturación ${ }^{231}$, relevante, dominante, residual, emergente ${ }^{232}$ y subalterno ${ }^{233}$ ), histonemas (componentes mínimos cuya presencia o ausencia determinan la viabilidad de un elemento histórico), diégesis (tiempo interno del relato historiográfico), campos de historialidad, causas, historiotipos (enunciado histórico básico de conceptos, procesos y trasuntos), ucronías (tiempos indefinidos, como los de la mítica), heterocronías (tiempos falsarios, ya que en su seno no ocurre lo atribuido), trasuntos, fómites (causas excipientes y promovedoras), procesos (los de corta duración o "recurrentes" y los de largo plazo o "direccionales"234), glocalismos (globalidades localmente reapropiadas), estilos, vectores (índices interactivos relacionales), factores, valores, hechos, facta (hechos históricos indubitables, ya nombrados al final del epígrafe II), variables y moléculas históricas (unidad mínima de significado histórico); y en segunda instancia, los cronóforos (portadores de tiempo): inconscientes ${ }^{235}$, anagoges, cronotipos, imaginarios, intornos (entornos interiores de un grupo o comunidad ${ }^{236}$ ), cosmovisiones, habitus (entendido como "un conjunto de relaciones históricas depositadas en los cuerpos individuales bajo la forma de esquemas mentales y corporales de percepción, apreciación y acción"237.), lebenswelten, ideologías, epistemes (prácticas dominantes en unas unidades de análisis ${ }^{238} \mathrm{O}$, dicho de otro modo: "conjunto de reglas [...] lógicas, a partir de las que se organiza la cien-

231. ROSTOW, Walt W.: The stages of economic growth: a non-communist manifesto. Cambridge, CU, 1991, pp. 106-122; el autor habla de "sociedad tradicional" en lugar de "proteidades", de "condiciones previas para el impulso inicial" en vez de "aprioris", de "impulso inicial" por "impulso", de "marcha hacia la madurez" en lugar de "madurez" y de "era del alto consumo en masa" en vez de "saturación", mas proponemos nuestros términos por ser más escuetos y omniabarcantes a la par, ya que Rostow consigna estas cinco etapas como ínsitas del crecimiento socioeconómico, mientras que su aplicación es traspolable a mayores alcances analíticos.

232. WILLIAMS, Raymond: Marxismo y literatura. Buenos Aires, Las cuarenta, 2009, pp. 165-174. La relevancia no supone dominio y es característica perenne (como los "hechos relevantes" aludidos al principio de nuestro trabajo), entretanto lo dominante, aunque suele connotar relevancia, es transitorio.

233. BARRAGÁN, Rossana y RIVERA, Silvia (comps.): Debates poscoloniales: Una introducción a los Estudios de la Subalternidad. La Paz, Historias-SEPHIS-Aruwiyiri, 1997.

234. VOGT, Evon Z.: Sobre los conceptos..., op. cit., pp. 73-86.

235. La siguiente observación levistraussiana da cuenta de la importancia de los inconscientes para la cliología, ya que "el inconsciente [es] el elemento mediador entre yo y los demás [pues] nos hace coincidir con las formas de actividad que son al mismo tiempo nuestras y de los otros, condiciones de todas las vidas mentales, de todos los hombres y de todos los tiempos"; LÉVI-STRAUSS, Claude: "Introducción a la obra de Marcel Mauss", en MAUSS, Marcel: Sociología y Antropología. Madrid, Tecnos, 1979, pp. 13-42 (cita en p. 28).

236. Es un concepto debido a FRANÇOIS, Charles: El uso de modelos sistémicos-cibernéticos como metodología científica. Buenos Aires, GESI-AATGSC, 1985, pp. 45 y 59s.

237. BOURDIEU, Pierre y WACQUANT, Loïc J. D.: Respuestas: por una antropología reflexiva. México, Grijalbo, 1995, p. 23.

238. MUDROVCIC, María Inés: Historia, narración..., op. cit., p. 100. 
cia [o] saber de cada época"239), planos (los diversos enfoques de un estudio histórico), territorios, modas (como la media matemática, en cuanto a la preponderancia de un estatus societal), utopías, heterotopías (lugares evocadores de realidades ajenas a los mismos ${ }^{240}$ ), yerros (los olvidos, omisiones y otros errores como acicates para lo que cabe subsanar), motivaciones, idealtipos (la weberiana tipologización de caracteres sociohistóricos, que son elementos de las constantes históricas), generaciones, algoritmos (conjunto ordenado y finito de operaciones que permite hallar la solución de un problema), retroversiones (los "retrocesos" históricos), marcas (hitos de significado en un cronotopo, ya que "lo histórico no reside en el acontecimiento o en la transformación sino en un estilo de conducta colectiva para lo cual todo es significativo" 241 ; un ejemplo objetual son los "semióforos"242), ideas-fuerza (metaconceptos alrededor de los cuales, según tiempos o incluso atemporalmente, se organizan muchos otros conceptos ${ }^{243}$ : como el paradigma, o el régimen, o el llamado "principio regulador"244), deseos, apocalipsismos, histodinamias (procesión histórica más o menos extensa), histonimias (metonimias históricas, reflejadas en la historia que trata, por distintos caminos, de "ampliar una experiencia particular hasta alcanzar las dimensiones de una experiencia más general, que por esta misma razón resulta accesible como experiencia a hombres [...] de otro tiempo" 245 , es decir: procesos en los que lo sucedido en una parte del "todo" está determinado por la dinámica inherente a esa "totalidad" considerada -un ejemplo tipo es la "mónada" benjaminiana-), histocinéticas (velocidad de los cambiantes aconteceres históricos), historicidades (las distintas concurrencias naturales y humanas en el tiempo), historritmias (cadencia histórica signada por intervalos rítmicos o aleatorios ${ }^{246}$ ), historialidades (los varios registros de nuestros pasados, con especial atención a la escritura historiográfica), mentalidades (modos de interpretar las creencias) y creencias (apropiaciones cognitivas y afectivas de toda laya).

239. BERMEJO, José C.: Introducción a la sociología del mito griego. Madrid, Akal, 1979, p. 59.

240. FOUCAULT, Michel: Des espaces autres, conferencia dictada en el Cercle des Études Architecturals (París), el 14 de marzo de 1967.

241. LEFORT, Claude: "Société «sans histoire» et historicité", en Cahiers Internationaux de Sociologie, París, no 12, 1952, pp. 91-114 (cita en p. 102).

242. POMIAN, Krzysztof: Sobre la..., op. cit., p. 131, define "semióforo [como] un objeto visible dotado de significado".

243. VALENCIA, Guadalupe: Entre cronos..., op. cit., p. 132; dichos metaconceptos vienen a ser lo que Ranke calificó como "ideas-rectoras" (RANKE, Leopold von: Sobre las épocas..., op. cit., pp. 75-82), y Mauss como "ideas-signos" (MAUSS, Marcel: Sociología..., op. cit., p. 285)

244. PANOFSKY, Erwin: Arquitectura gótica y pensamiento escolástico. Madrid, La Piqueta, 1986, p. 39.

245. LÉVI-STRAUSS, Claude: Antropología estructural. Barcelona, Paidós, 1987, p. 64.

246. LEFEBVRE, Henri y RÉGULIER, Catherine: "Le projet rythmanalytique", en Communications, París, no 41, 1985, pp. 191-199. 
Con lo expuesto, por emplear una metáfora lefebvriana, hemos considerado "cada pieza separada según su forma y según su función. El conjunto de las piezas es [...] más que su yuxtaposición o su suma: funciona. Sin embargo, el [paralipómeno] se descompone analíticamente en esas piezas, cada una de las cuales tiene su significación en el todo que se recompone a partir de ellas"247; por supuesto, todos estos elementos del paralipómeno, como "los [mismos] hechos [que estudian], nos suministran explicaciones" 248 descriptivas, particularmente "a través de sus relaciones" 249 desde el pertinente clioanálisis. Partiendo de este gran mallazo teórico queda los más importante, que es la labor del historiador sobre la historia; la tarea de historiar siempre es ingente, mas el auxilio del paralipómeno bien nos la puede hacer más llevadera por más meridiana, ya que, por más artesano que sea un cliólogo, el indispensable apoyo científico en todo caso supone una ventaja crucial para un mayor avance y profundización en nuestro oficio.

247. LEFEBVRE, Henri: "Reflexiones sobre el estructuralismo y la historia”, en SAZBÓN, José (dir.): Estructuralismo..., op. cit., pp. 131-156 (cita en p. 136).

248. CARNAP, Rudolf: Fundamentación lógica de la física. Buenos Aires, Sudamericana, 1969, p. 14.

249. BERMEJO, José C.: Introducción a la historia teórica. Madrid, Akal, 2009, p. 297. 